\title{
Taylor Rules and the Great Inflation
}

\author{
Alex Nikolsko-Rzhevskyy* \\ University of Memphis \\ David H. Papell ${ }^{* *}$ \\ University of Houston
}

April 9, 2012

\begin{abstract}
Can U.S. monetary policy in the 1970s be described by a stabilizing Taylor rule when policy is evaluated with real-time inflation and output gap data? Using economic research on the full employment level of unemployment and the natural rate of unemployment published between 1970 and 1977 to construct realtime output gap measures for periods of peak unemployment, we find that the Federal Reserve did not follow a Taylor rule if appropriate measures are used. We estimate Taylor rules and find no evidence that monetary policy stabilized inflation, even allowing for changes in the inflation target. While monetary policy was stabilizing with respect to inflation forecasts, the forecasts systematically under-predicted inflation following the 1970s recessions and this does not constitute evidence of stabilizing policy. We also find that the Federal Reserve responded too strongly to negative output gaps.
\end{abstract}

We thank Robert Gordon, Andrew Levin, Edward Nelson, Edmund Phelps, and participants at the 2009 CIRANO Workshop on Macroeconomic Forecasting, Analysis, and Policy with Data Revisions, Emory University, Baylor University, Texas A\&M University, and the San Francisco Fed for helpful comments and discussions.

\footnotetext{
* Department of Economics, University of Memphis, Memphis, TN 38152. Tel: +1 (901) 678-4627 Email: nklrzhvs@memphis.edu

Department of Economics, University of Houston, Houston, TX 77204-5882. Tel/Fax: +1 (713) 743-3807/3798. Email: dpapell@uh.edu
} 


\section{Introduction}

Can U.S. monetary policy in the 1970 s be described by a stabilizing Taylor rule, where the Federal Reserve increased the interest rate more than point-for-point with inflation? Or is it better described as a series of stop-start policies, where repeated abortive attempts to fight inflation over-stimulated the economy and ultimately produced the Great Inflation?

At first glance, the answer to this question seems obvious, as Federal Reserve policy during the 1970s is not normally thought of as satisfying a stabilizing rule and, in retrospect, certainly produced unfavorable outcomes. Meltzer (2009a), for example, describes the Federal Reserve during this period as knowing only two speeds: too fast and too slow. Taylor (1999) shows that the actual federal funds rate during the 1970s was considerably below the rate implied by the Taylor rule. The large literature on estimated Taylor rules, notably Clarida, Gali, and Gertler (2000), finds that the Federal Reserve did not raise the nominal interest rate more than point-for-point with inflation, and thus the Taylor principle was not satisfied, during the 1970s.

Orphanides (2003a,b) has forcefully challenged this consensus. His argument is that the output gap used for estimating Taylor rules based on revised data is much smaller than the realtime data known to Federal Reserve officials at the time that policy decisions were made. Using data produced by the Council of Economic Advisors (CEA), he shows that Federal Reserve policy in the 1970 s is consistent with a stabilizing Taylor rule with a 2 percent inflation target.

While Orphanides' argument for the use of real-time data has become virtually universally accepted for Taylor rule estimation, his use of CEA output gaps for this period is controversial. Taylor (2000) argued that the CEA estimates of potential GDP and its growth rate were politicized starting in the late 1960 s and that serious economic analysts paid no attention to them. Cecchetti et al (2007) propose an alternative real-time output gap measure, the percentage 
deviation of GDP from its trend, computed by the Hodrick-Prescott (HP) filter, using only data available at the time. Their HP filtered output gaps are smaller than Orphanides' output gaps throughout the 1970s and are close to current Congressional Budget Office (CBO) estimates with revised data. Levin and Taylor (2009) use the same measure.

The question of whether the Federal Reserve followed a Taylor rule in the 1970s is not simply a matter of whether revised or real-time data is used. Using real-time HP filtered output gaps, we calculate the federal funds rate implied by a stabilizing Taylor rule with a 2 percent inflation target. The implied policy rate is closer to the rate calculated using revised $\mathrm{CBO}$ data than real-time CEA data. It is consistently higher than the actual rate, supporting the view that Federal Reserve policy was too stimulative during this period and, therefore, contributed to the Great Inflation. Monetary policy analysis for the 1970s does not just depend on the use of realtime versus revised data; it depends crucially on what real-time data is used.

The leading method for calculating output gaps in the 1970s was linear detrending, followed by quadratic detrending. Following Cecchetti et al (2007), we calculate real-time detrended output gaps, but use linear and quadratic detrending. This exactly replicates the output gap a researcher in the 1970s would have calculated at the end of the sample. Both sets of output gaps are smaller in magnitude than the CEA estimates and larger than the HP filtered estimates. Most importantly, the policy rates implied by a Taylor rule with linear or quadratic detrended output gaps are consistently higher than the actual rates, supporting the conventional view that Federal Reserve policy was too stimulative during this period.

Which real-time output gap measure should be used for monetary policy evaluation during the Great Inflation? We pose the following question: What would have been a reasonable metric for a researcher to approximate the output gap during this period? Our answer is to use 
Okun's Law, where the output gap is equal to a (negative) constant times the difference between unemployment and the natural rate of unemployment. The use of Okun's Law leads to our next question: What were the "real-time" estimates of the natural rate of unemployment and the Okun's Law coefficient during the 1970s, particularly during the recession of 1975. Using research published during the 1970s, mostly in Brookings Papers on Economic Activity, we document that, by 1975, a consensus had developed around 5.5 percent for the natural rate of unemployment and -3.0 for the Okun's Law coefficient.

We use real-time estimates of the natural rate of unemployment to evaluate the four realtime output gap measures. Focusing on 1975:2, the quarter of peak unemployment, we show that the real-time Okun's law output gap approximation is smaller than the CEA estimated output gap, but larger than the HP detrended output gap. The output gaps constructed using real-time linear and quadratic detrending are much closer to the real-time Okun's law approximation than either the CEA or the HP filtered measures. The same picture emerges from considering 1971:4, the quarter of peak unemployment following the recession of 1969-1970, although the evidence for the real-time measure of the natural rate of unemployment is not as comprehensive.

We proceed to estimate Taylor rules for the late 1960s and 1970s, using real-time inflation and four real-time measures of the output gap: linear detrended, quadratic detrended, HP detrended, and CEA, as well as within-quarter CEA output gap forecasts. ${ }^{1}$ With all four output gap measures, the coefficient on the four-quarter average inflation rate is below one, so that monetary policy did not follow a stabilizing Taylor rule. Using one to four-quarter inflation forecasts, the coefficient is both above and significantly different from one for some specifications. This does not, however, provide evidence that the Federal Reserve followed a

\footnotetext{
${ }^{1}$ Murray, Nikolsko-Rzhevskyy, and Papell (2009) estimate Markov switching models for forward-looking Taylor rules from 1965:4 - 2007:1, using real-time CEA, linear detrended, and HP filtered output gaps.
} 
stabilizing Taylor rule. The inflation forecasts are consistently lower than the inflation rates during and immediately following the two recessions of the 1970s. It appears that the Federal Reserve was overly optimistic about how quickly recessions would bring inflation down and, as a result, failed to sufficiently raise interest rates. ${ }^{2}$

The second aspect of the Taylor rule involves the response of the interest rate to the output gap. With both linear and quadratic detrended output gaps, the estimated coefficients are higher than Taylor's postulated coefficient of 0.5 . The response to the output gap, especially during times of peak unemployment, contributed to making monetary policy too stimulative in the 1970 s.

Following Levin and Taylor (2009), we investigate stop-start monetary policy by allowing for changes in the inflation target starting in 1970:2, when Arthur Burns became the Federal Reserve Chairman, and in 1976:1, the start of the election year. With four-quarter average real-time inflation rates, the inflation coefficient is not significantly different from one, and consequently there is no well-specified inflation target, for any of the real-time output gap measures. With one to four-quarter inflation forecasts, the inflation forecast coefficient is significantly different from one in most cases and, for these specifications, the target increased in either 1970:2 and/or 1976:1. These results, however, do not support Levin and Taylor's conclusion that the Federal Reserve stabilized inflation around an increasing target, as stabilizing inflation forecasts is not the same as stabilizing inflation when the forecasts are too optimistic.

\section{Taylor Rules with Real-Time Data for the 1970s}

Following Taylor (1993), the monetary policy rule postulated to be followed by central banks can be specified as

\footnotetext{
${ }^{2}$ Kozicki and Tinsley (2009) estimate time-varying parameter models with real-time inflation forecasts and unemployment gap estimates. The estimated response to inflation falls below unity in the mid-1970s.
} 


$$
i_{t}^{*}=\pi_{t}+\phi\left(\pi_{t}-\pi^{*}\right)+\gamma y_{t}+r^{*}
$$

where $i_{t}^{*}$ is the target for the short-term nominal interest rate, $\pi_{t}$ is the inflation rate, $\pi^{*}$ is the target level of inflation, $y_{t}$ is the output gap, or percent deviation of actual real GDP from an estimate of its potential level, and $r^{*}$ is the equilibrium level of the real interest rate. The coefficients $\phi$ and $\gamma$ are both positive. It is assumed that the target for the short-term nominal interest rate is achieved within the period so there is no distinction between the actual and target nominal interest rate.

According to the Taylor rule, the central bank raises the target for the short-term nominal interest rate if inflation rises above its desired level and/or output is above potential output. The target level of the output deviation from its natural rate $y_{t}$ is 0 because, according to the natural rate hypothesis, output cannot permanently exceed potential output. The target level of inflation is positive because it is generally believed that deflation is much worse for an economy than low inflation. Taylor assumed that the output and inflation gaps enter the central bank's reaction function with equal weights of 0.5 and that the equilibrium level of the real interest rate and the inflation target were both equal to 2 percent.

The parameters $\pi_{t}^{*}$ and $r^{*}$ in Equation (1) can be combined into one constant term $\mu=r^{*}-\phi \pi^{*}$, which leads to the following equation,

$$
i_{t}=\mu+\lambda \pi_{t}+\gamma y_{t}
$$


where $\lambda=1+\phi$. Because $\lambda>1$, the real interest rate is increased when inflation rises and so the Taylor principle is satisfied. ${ }^{3}$ With Taylor's original coefficients, $\mu=1$ percent, $\lambda=1.5$, and $\gamma$ $=0.5$.

Orphanides (2003a,b) posed the following question. Suppose that the Federal Reserve had followed a Taylor rule with the coefficients as in Equation (2) in the 1970s. How would the implied federal funds rate compare with the actual rate set at the time? While Taylor (1993) had used the same metric for 1987 - 1992 in his original paper, Orphanides' addressed the question with real-time data and used the answer to analyze the causes of the Great Inflation. ${ }^{4}$

Figure 1 (top panel) depicts the revised and real-time output gaps. Data on nominal and real GNP were published by the Commerce Department in the monthly publication, Survey of Current Business, and real-time quarterly vintages starting in 1965:4 are available on the Federal Reserve Bank of Philadelphia web site. Revised estimates of potential output are published by the CBO in The Economic Outlook, while the real-time output gap data published by the CEA was collected by Orphanides from the Economic Report of the President and Business Conditions Digest. Since the data are published with a one-quarter lag, real-time inflation for quarter $t$ is defined as the log change ending in quarter $t-1$ and the real-time output gap for quarter $t$ as the $\log$ difference between real and potential output in quarter $t-1$, in percent. ${ }^{5}$ It is

\footnotetext{
${ }^{3}$ Woodford (2003) generalizes the Taylor principle and shows that determinacy of equilibrium can occur with $\lambda<1$ if $\gamma$ is sufficiently large. This generalization, however, requires a non-vertical long-run Phillips curve.

${ }^{4}$ When Taylor rules are estimated, rather than used for policy evaluation, it is standard practice to allow for partial adjustment of the interest rate to its target. We incorporate partial adjustment in the context of estimation below.

${ }_{5}^{5}$ Orphanides (2000) provides more information about how the data were constructed. Orphanides (2003b, 2004) uses CEA real-time output gap data based on within-quarter forecasts, which differs slightly from the data used in these papers (and from each other). We use the one-quarter-lagged data for comparability with other methods for constructing real-time output gaps.
} 
immediately apparent from Figure 1 that the difference between revised and real-time data is substantial, with by far the largest difference at the trough of the recession in $1975 .{ }^{6}$

The implications for using Orphanides' real-time output gap measure, rather than a revised output gap measure, are shown in the bottom panel of Figure 1. The federal funds rate implied by the Taylor rule in (2), with Taylor's original coefficients, is depicted using revised and real-time data, along with the actual federal funds rate. This figure summarizes Orphanides' argument. With revised data, the actual federal funds rate is consistently below the implied rate, indicating that policy was too stimulative and caused (or at least contributed to) the Great Inflation. With real-time data, the actual federal funds rate is very close to the implied rate for considerable periods of time. In fact, the federal funds rate implied by the Taylor rule is below the actual rate during the period following the recessions of $1969-1970$ and 1975 , leading to Orphanides' conclusion that, had the Federal Reserve followed a Taylor rule during this period, it would have made inflation worse. ${ }^{7}$

Taylor (2000) was the first to criticize Orphanides' output gap measure, calling it "flawed conceptually, exaggerated in magnitude, and overemphasized in comparison with other problems." While agreeing that, because there is no record of a potential output series produced by the Federal Reserve in the 1970s, there is a problem in constructing a real-time output gap measure, he argued that assuming the Federal Reserve used the series produced by the CEA is "analogous to assuming a can opener."

Cecchetti et al (2007) propose an alternative real-time output gap measure, the percentage deviation of GDP from its trend, computed by a Hodrick-Prescott (HP) filter, using only data

\footnotetext{
${ }^{6}$ While our revised data can differ from Orphanides' because we use April 2009 and he uses October 1999 CBO numbers, the differences are miniscule.

${ }^{7}$ Since the differences between revised and real-time output gaps are much larger than the differences between revised and real-time inflation, it is clear that the use of Orphanides' real-time output gap is what drives the result.
} 
available at the time. Starting in 1969:1, the real-time output gap is computed by taking the percentage deviation of the last observation from its HP trend, with a smoothing parameter of 1600 and data from 1947:1 used to compute the trend. Since the GDP data was available with a one-quarter lag, the observation for 1969:1 incorporates data through 1968:4. With each new observation, another data point is added to the trend. The last point in the sample is 1979:2, which uses data through 1979:1. In Figure 1 (top panel), we depict the HP filtered real-time output gaps. They are much smaller than the real-time CEA estimates throughout the 1970s, and track the revised CBO estimates fairly closely. ${ }^{8}$

Figure 1 (bottom panel) illustrates the implications of using HP filtered real-time output gaps, rather than real-time CEA estimates, for the analysis of Taylor rules in the 1970s. The implied federal funds rate is much closer to the rate implied by the revised data than to either the rate implied by the CEA estimates or to the actual federal funds rate. The message from the use of HP filtered real-time output gaps is clear. Using data available to the Federal Reserve at the time that monetary policy decisions were made, the actual federal funds rate is consistently below the rate implied by the Taylor rule. The use of real-time, rather than revised, data does not affect the conclusion that monetary policy was too stimulative and contributed to the Great Inflation.

It is not clear, however, that HP filtering produces a good real-time output gap measure for the 1970s. The most obvious problem, of course, is that the technology to compute HP filters did not exist until the early 1980s. Cecchetti et al (2007) recognize this, but argue that the capacity to compute more rudimentary trends did exist at the time. The leading method to construct trends at the time was linear detrending, as used by Taylor (1980), followed by

\footnotetext{
${ }^{8}$ We also calculated, but do not report, real-time output gaps using HP and band-pass filters with forecasted future values of output, as described in Watson (2007). The resultant output gaps were similar to those obtained with the standard HP filter.
} 
quadratic detrending. ${ }^{9}$ In order to see how HP filtering compares with these methods, we estimate real-time linear and quadratic detrended output gaps using the same data as for the HP detrended output gaps described above.

Real-time detrended output gaps, as well as CBO revised gaps and CEA real-time gaps for reference, are depicted in Figure 2 (top panel) for linear detrending and Figure 3 (top panel) for quadratic detrending. The linear and quadratic output gaps are consistently larger than the revised $\mathrm{CBO}$ output gaps and the HP filtered output gaps depicted in Figure 1, but smaller than the CEA output gaps. The implications of this choice are illustrated in the bottom panels of Figures 2 and 3. While the federal funds rate implied by the Taylor rule with real-time linear or quadratic detrended output gaps is lower than the rate implied with revised data, it is generally higher than the actual federal funds rate. Most importantly, the federal funds rate that the Federal Reserve would have set if it followed a Taylor rule with real-time linear or quadratic detrended output gaps was higher than the actual federal funds rate during the periods following the recessions of 1969-1970 and 1974-1975. Although the implied federal funds rate with real-time linear or quadratic detrended output gaps is lower than the implied rate with real-time HP detrended data, the conclusion that monetary policy was too stimulative and contributed to the Great Inflation is the same.

\section{Real-Time Output Gaps for the 1970s}

Using different measures of real-time output gaps, we have shown that you can reach completely different conclusions regarding whether or not the Federal Reserve followed a Taylor rule during the 1970s. With CEA output gaps, the Federal Reserve followed a Taylor rule but failed to prevent the Great Inflation. With real-time HP filtered output gaps, the federal funds rate implied by a Taylor rule was about the same as with revised CBO data, and monetary policy

\footnotetext{
${ }^{9}$ Taylor (1980) performed linear detrending using revised data.
} 
was clearly too stimulative. With real-time linear and quadratic detrended output gaps, the implied federal funds rate was lower than with revised $\mathrm{CBO}$ data, but policy was still too stimulative.

\subsection{Real-Time Okun's Law Output Gaps}

Which output gap measure best approximates the perceptions of policymakers in the 1970s? While one cannot hope for a definitive answer, we propose the following metric. One of the best-known rules of economics is Okun's Law, which states that the output gap equals a (negative) coefficient times the difference between current unemployment and either the unemployment rate at full employment or the natural rate of unemployment. Using academic research available to policymakers and writing of policymakers themselves, we use Okun's Law to construct "rule-of-thumb" output gaps based on real-time unemployment rates, perceptions of the natural rate of unemployment, and perceptions of the coefficient relating the unemployment differential to the output gap. While we cannot construct a time series for these gaps, we focus on 1975, the year of the worst recession (at that time) since the Great Depression, as well as on the recession of 1970 following the boom of the late 1960s, and investigate the congruence between the real-time Okun's Law output gaps and the real-time output gaps computed by the CEA and with various detrending methods.

Real-time unemployment rates are easily available. Unemployment rates were published by the Bureau of Labor statistics and are available on the Federal Reserve Bank of Philadelphia web site. Constructing the real-time Okun's Law coefficient is also straightforward. While Okun (1962) proposed a coefficient of -3.3, and current work such as Abel and Bernanke (2005) and Knotek (2007) uses -2.0, all contemporary research that we found used a coefficient of -3.0. This 
includes the 1976 Economic Report of the President, Gordon (1977), and the Gordon (1978) and Dornbusch and Fischer (1978) intermediate macroeconomics textbooks.

Estimating real-time natural rates of unemployment for the $1970 \mathrm{~s}$ is not as straightforward. Two interacting factors complicate the analysis. First, between the late-1960s and the mid-1970s, the natural rate (or accelerationist) hypothesis of Friedman (1968) and Phelps (1968) went from an original proposal to a generally accepted theory. Second, between the early 1970s and the mid 1970s, the structural shift hypothesis of Perry (1970) that demographic changes had raised the unemployment rate at full employment and/or the natural rate of unemployment became both generally accepted and refined.

The official value of the full employment unemployment rate was set at 4.0 percent in the 1962 Economic Report of the President. This value was based on evidence that actual GNP in mid-1955, when the unemployment rate was close to 4.0 percent, was equal to potential output. ${ }^{10}$ While the official value remained unchanged until the 1977 Report, when it was raised to 4.9 percent with a natural rate interpretation, the 4.0 percent number is a misleading representation of real-time beliefs in the 1970s. As emphasized by Taylor (2000), the text of the 1977 Report makes it clear that the CEA staff did not believe the 4.9 percent number. After describing how the CEA "has estimated that the full-employment unemployment rate equivalent to 4.0 percent in 1955 is now 4.9 percent," the text almost immediately goes on to say that there are other factors that were not considered and that "it is likely that they have raised the full-employment unemployment rate even higher than the current estimate, perhaps closer to $5 \frac{1}{2} 2$ percent." Later

\footnotetext{
${ }^{10}$ Clark (1979) describes the official CEA calculation of potential output through 1976 as a judgmental variant of the 1962 procedure.
} 
in the same chapter, it is suggested that policy makers "should watch closely for signs of accelerating wage inflation when the overall rate of unemployment falls to about 5 1/2 percent.",11

The complications involved in estimating real-time natural rates of unemployment can be illustrated by using the most straightforward method to estimate the natural rate, calculating the average of past unemployment rates. ${ }^{12}$ For example, the 1970 Economic Report of the President reported annual unemployment rates for 1948 - 1969, producing a real-time estimate using this methodology of 4.7 percent for 1970 . While this is considerably above the official value, we will see below that it is consistent with other estimates produced at the time. But now consider 1975, where the Economic Report of the President reported annual unemployment rates for 1948 1974. The average unemployment rate for 1970 - 1974 was 5.4 percent, raising the $1948-1974$ average to 4.8 percent. We will see below that, because the higher unemployment rates starting in 1970 were considered to be caused by demographic shifts rather than business cycle fluctuations, real-time perceptions of the natural rate in 1975 were more consistent with the higher 1970 - 1974 average than the lower 1948 - 1974 average.

\subsection{Research on the Natural Rate of Unemployment in the 1970s}

Starting in the late 1960s and continuing through the mid-1970s, a considerable amount of high-profile research showed that 4.0 percent was not a realistic number for either the fullemployment unemployment rate or the natural rate of unemployment. A very early estimate of the natural rate of unemployment was contained in the report of the Pre-Presidential Task Force on Inflation (1969), written in late 1968 and forwarded to President-Elect Nixon by Arthur Burns, who was in charge of all 17 task force reports, on January 18, 1969. The task force, which included Edmund Phelps as a member, wrote that they believed the normal level of

\footnotetext{
${ }^{11}$ See Economic Report of the President (1977), pages 51 and 56.

${ }^{12}$ Hall (1999) discusses the advantages of this approach.
} 
unemployment was in the $4-5$ percent range. The report used the term "normal level of unemployment" in exactly the same way that "natural rate of unemployment" would be used today, as the unemployment rate below which inflation would accelerate. ${ }^{13}$

The year 1970 marked the initial publication of Brookings Papers on Economic Activity (BPEA), which quickly became a journal widely read by both academics and policy makers. During the 1970s, BPEA published numerous articles on inflation, unemployment, and Phillips curves, both from a natural rate and a non-natural rate perspective. Hall (1970) postulated an "equilibrium level of unemployment" of 4.0 to 5.0 percent unemployment that, if maintained permanently, would produce inflation of 3.0 to 4.0 percent per year. He provided a natural rate interpretation of the equilibrium level of unemployment which was consistent with both the Task Force on Inflation's normal level and the average unemployment rate for $1948-1969$.

Perry (1970) advanced the structural shift hypothesis, which initiated research on how demographic changes affect the unemployment rates consistent with various levels of inflation. He introduced the concept of a weighted unemployment rate, which adjusts the official unemployment rate for the differences in the contributions individuals make to production when they are employed, and argues that the same unemployment rate was associated with a much tighter labor market in 1970 than in the mid-1950s. His calculations, which explicitly reject the accelerationist hypothesis, show that a 3.8 percent unemployment rate was consistent with 3.0 percent inflation in the mid-1950s. By 1970, the unemployment rate consistent with 3.0 percent inflation had risen to over 5.0 percent.

Between 1969:4 and 1970:4, inflation accelerated even though the unemployment rate rose from 3.6 percent to 5.9 percent. Gordon (1971) calculated that a steady 3.0 percent long-run

\footnotetext{
${ }^{13}$ Phelps (1972) described the equilibrium region for the unemployment rate in the 1969 Task Force report as around 4.5 percent.
} 
inflation rate required an unemployment rate of 5.2 percent, compared with 4.1 percent in 1956. Although he rejected the accelerationist hypothesis, he calculated that, if the hypothesis held, the natural rate of unemployment was 5.5 percent. One year later, however, Gordon (1972) gave equal prominence to natural-rate and non-natural rate versions of the Phillips Curve. In the variable coefficient version of the model, where the coefficient on lagged inflation rises toward unity as the inflation rate increases, the natural rate of unemployment is 4.8 percent. Averaging the two Gordon papers produces a real-time natural rate of unemployment for 1971 - 1972 of 5.2 percent. While this is lower than the revised CBO estimate of 6.0 percent, it is higher than the real-time CEA number of 4.0 percent.

After stabilizing between 4.8 percent and 5.1 percent in 1973 and early 1974, unemployment rose to 5.6 percent in $1974: 3$, 6.7 percent in $1974: 4,8.1$ percent in $1975: 1$, and 8.8 percent in 1975:2, and stayed above 7.0 percent until late 1977. By this point, the combination of the natural rate (Phelps-Friedman) and structural shift (Perry) hypotheses had clearly become the dominant view of the Phillips curve. Hall (1974), in a paper that explicitly accepted the accelerationist hypothesis, refined the structural shift hypothesis and estimated the natural rate of unemployment at 5.5 percent. Modigliani and Papademos (1975) estimated a noninflationary rate of unemployment of just over 5.5 percent. Wachter (1976) proposed a new methodology for estimating shifts in the natural rate of unemployment. He assumed a stable relationship between wage changes and unemployment of males aged 25 to 54 , with a natural rate of unemployment of 2.9 percent in both 1956 and 1974, and calculates that, because of the increases of teenagers and women (with historically higher unemployment rates) in the labor force, the overall natural rate of unemployment had risen from about 4.0 percent in 1956 to approximately 5.5 percent in 1974. Gordon (1977), using males aged 25-54 as the stable 
reference group, reported an estimate of the natural rate of unemployment for 1974 of 5.42 percent. He also investigated alternative possibilities for a reference group, including males 3544, all 25-54, males 25+, and all 25+, and estimated natural rates of unemployment for 1974 between 5.25 and 5.72 percent, with an average (including males 25-54) of 5.51 percent. $^{14}$ Between the Hall, Modigliani and Papademos, Wachter, and Gordon papers, a natural rate of unemployment of 5.5 percent for 1975 seems reasonable. This is lower than the revised CBO estimate of 6.2 percent but much higher than the real-time CEA estimate of 4.0 percent. ${ }^{15}$

\subsection{Calculating Real-time Output Gaps from Real-time Natural Rates of Unemployment}

We can now answer the question posed at the beginning of Section 3.1. Which (if any) real-time output gap measure would be congruent with a calculated real-time output gap for the 1970s, using Okun's Law with a coefficient of -3.0. We first focus on the recession year of 1975. Unemployment peaked at 8.9 percent in 1975:2. With a natural rate of unemployment of 5.5 percent and an Okun's Law coefficient of -3.0, the real-time output gap for 1975:3 (assuming a one-quarter lag before the data was released) was -10.2 percent. While this is much lower than the CEA number (-16.2 percent), it is considerably higher than the HP filtered number $(-5.9$ percent). The output gaps constructed by real-time linear and quadratic detrending, -10.8 percent and -10.4 percent, respectively, are much closer to the real-time gap constructed by using Okun's Law than either the CEA or the HP filtered numbers.

\footnotetext{
${ }^{14}$ Gordon (1977) is the only paper we cite that was not published in Brookings Papers. It was originally presented at the Carnegie-Rochester Conference on Public Policy in April 1974, but did not contain estimates of the natural rate of unemployment. The revised version with these estimates was circulated as a working paper in September 1976.

${ }^{15}$ Orphanides and Williams (2005), citing Hall (1970) and Perry (1970), argue that perceptions of the natural rate of unemployment rose to about 4.5 percent in 1970. While they state that natural rate estimates continued to rise during the 1970s, they do not raise their real-time estimates until the publication of the higher CEA estimates in 1977. Nelson (2005), citing newspaper articles reflecting the views of prominent economists, also argues that 4.5 percent is an appropriate real-time estimate of the natural rate until 1977. Neither of these papers, however, considers the post-1970 research cited in this paper. Kozicki and Tinsley (2006) use a time-varying parameter framework with real-time forecast data to estimate the Federal Reserve's ex ante perceptions of the natural rate of unemployment. They estimate 5.2 percent for 1970:1 - 1975:2 and 5.3 percent for 1975:3 - 1978:1, quite close to our narrative results.
} 
We next focus on the earlier (and smaller) recession year of 1971. Unemployment peaked at 6.0 percent in 1971:4. With a natural rate of unemployment of 5.2 percent and an Okun's Law coefficient of -3.0 , the real-time output gap for 1972:1 (again assuming a one-quarter lag before the data was released) was -2.4 percent. This is again lower than the CEA number (-6.7 percent) and higher than the HP filtered number ( 0.0 percent). It is striking that, with unemployment at 6.0 percent, a figure higher than any real-time estimate of the natural rate, real-time HP detrending (assuming it was possible) would have produced a result that output was equal to potential output. The output gaps constructed by real-time linear and quadratic detrending, -2.2 percent and -2.9 percent, respectively, are again much closer to the real-time gap constructed by using Okun's Law than either the CEA or the HP filtered numbers.

These results are, of course, dependent on our choice of 3 percent for the Okun's Law coefficient and 5.5 percent for the natural rate of unemployment. An Okun's Law calculation with numbers appropriate for 1962, a coefficient of 3.3 and a full employment rate of unemployment of 4 percent, produces output gaps from 1969 to 1976 that are very close to the CEA estimates. In particular, the gaps are -6.6 percent in 1972:1 and -16.2 percent in 1975:3, almost identical to the CEA estimates. Using these numbers for 1972 and 1975, however, assumes that the economists and policymakers on Constitution Avenue (Federal Reserve Board) were not aware of the high profile research being presented on Massachusetts Avenue (Brookings). ${ }^{16}$

The revised CBO output gaps for 1971:4 (-1.3 percent) and 1975:2 (-5.0 percent) are much smaller than the real-time CEA estimates. The CBO currently reports estimates of the

\footnotetext{
${ }^{16}$ Burns (1979) argues that, while Federal Reserve policymakers were generally aware of what was happening in the labor market, they were slow to recognize the changing meaning of unemployment statistics. That is not the same, however, as completely ignoring the demographic and other changes that rendered the 4 percent full employment rate of unemployment obsolete.
} 
natural rate of unemployment of 5.9 percent for 1971 and 6.2 percent for 1975. Using a "2009" version of Okun's Law with a coefficient of -2.0 , the resultant output gaps would be -0.2 percent for 1971:4 and -5.4 percent for $1975: 2$, fairly close to the revised CBO estimates. ${ }^{17}$ Orphanides (2003a, 2004) ascribes the difference between the revised CBO and real-time CEA output gaps to two factors: misperceptions regarding the natural rate of unemployment and failure to recognize the productivity slowdown. While we agree that economists and policymakers failed to recognize the onset of the productivity slowdown and that the perceived natural rate of unemployment was, in retrospect, too low, misperceptions of the natural rate of unemployment were much smaller than what would have been calculated by using the official 4.0 full employment unemployment rate. Our resultant Okun's Law output gaps are, therefore, above the revised $\mathrm{CBO}$ output gaps and below the real-time CEA output gaps.

Using real-time measures of the natural rate of unemployment and the Okun's Law coefficient, it is clear that real-time linear and quadratic output gaps are a much closer approximation than output gaps constructed by real-time CEA estimates or HP detrended output gaps. Since the Taylor rule interest rate with real-time linear or quadratic detrended output gaps is consistently higher than the actual federal funds rate, monetary policy was too stimulative and contributed to the Great Inflation.

\section{Estimated Taylor Rules for the 1970s}

For the purpose of estimation, it has become common practice to specify a variant of the Taylor rule which allows for the possibility that the interest rate adjusts gradually to achieve its target level. Following Clarida, Gali, and Gertler (2000), we assume that the actual observable interest rate $i_{t}$ partially adjusts to the target as follows:

\footnotetext{
${ }^{17}$ We use 1971:4 and 1975:2 instead of 1972:1 and 1975:3 for this comparison because the former are the quarters of peak unemployment and, with revised data, there is no need to lag the data one quarter.
} 


$$
i_{t}=(1-\rho) i_{t}^{*}+\rho i_{t-1}+v_{t}
$$

Substituting (2) into (3) gives the following equation,

$$
i_{t}=(1-\rho)\left(\mu+\lambda \pi_{t}+\not \gamma_{t}\right)+\rho i_{t-1}+v_{t}
$$

Equation (4) can be estimated by nonlinear least squares.

\subsection{Estimated Taylor Rules}

Table 1 depicts estimates of Equation (4) for 1969:1 - 1979:4, using real-time inflation and the four real-time measures of the output gap: linear detrended, quadratic detrended, HP detrended, and CEA, that we analyzed graphically above. ${ }^{18}$ The linear and quadratic output gaps produce similar results as found with revised data in Clarida, Gali, and Gertler (2000). The inflation coefficients are 0.95 (linear) and 0.85 (quadratic). While the Federal Reserve raised the nominal interest rate when inflation increased, the increase was not sufficient to satisfy the Taylor principle and the policy was not stabilizing. ${ }^{19}$ The coefficient on the output gap is 0.70 (linear) and 0.96 (quadratic), both higher than Taylor's postulated 0.50 coefficient. The combination of the coefficient on inflation below one and the coefficient on the output gap above one-half is consistent with the visual evidence that the actual federal funds rate was consistently below the implied Taylor rule rate. The coefficients on the lagged interest rate, 0.42 (linear) and 0.62 (quadratic), indicate a fairly low degree of interest rate smoothing.

\footnotetext{
${ }^{18}$ We do not estimate models using the CBO output gaps because they are not real-time measures that could have been used by policymakers.

${ }^{19}$ Both coefficients are significantly greater than zero, but neither is significantly different from one. It is therefore possible that the actual coefficient is greater than one even though the estimated coefficient is less than one.
} 
While the inflation target and equilibrium real interest rate cannot both be identified from estimates of the constant $\mu=r^{*}-\phi \pi^{*}$, it seems reasonable to assume that, during this period, the equilibrium real interest rate was more stable than the inflation target. An implied inflation target can be identified from estimates of $\mu$ and the inflation coefficient $\lambda=1+\phi$ by assuming a value of 2.0 percent for the equilibrium real interest rate. This procedure, however, is only valid if the estimate of the inflation coefficient $\lambda$ in Equation (4) is significantly greater than one, which requires that the estimate of $\phi$ in Equation (1) be significantly greater than zero. The results that the estimates of $\lambda$ with linear and quadratic detrending are not significantly different from unity are consistent with the view that the Federal Reserve did not have a well-defined inflation target during the 1970s.

Estimates with the CEA and HP detrended output gaps are also presented in Table 1. The inflation coefficient is 0.57 (CEA) and -0.11 (HP). They are both much smaller than the coefficients with the linear and quadratic output gaps, provide no evidence of stabilizing policy, and are consistent with the view that the Federal Reserve did not have a well-defined inflation target during the 1970s. The output gap coefficient is 0.56 (CEA) and 3.69 (HP). While the output gap coefficient for the CEA estimates is close to Taylor's postulated value of 0.50 , the coefficient for the HP detrended estimates is too large to be believable. The relative size of the coefficients is consistent with the evidence, presented above, that the CEA and HP detrended output gaps are too large and too small, respectively. The coefficients on the lagged interest rate, 0.66 (CEA) and 0.94 (HP), indicate a much higher degree of interest rate smoothing for the HP output gap than for the other output gap estimates.

Orphanides (2004) uses within-quarter output gap forecasts, rather than one-quarterlagged values, as his real-time-output gap measure. Since these estimates are available starting in 
1966:1, Table 1 also reports estimates of Equation (4) for 1966:1 - 1979:2. The estimates with CEA-forecast output gaps are similar to previous estimates with revised data, with an inflation coefficient of 0.96 , an output gap coefficient of 0.68 , and an interest rate smoothing coefficient of 0.78 . The inflation coefficient is not significantly different from unity. Adding three years of data does not substantially change the estimates with the other output gaps. While the inflation coefficient falls and the interest rate smoothing coefficient rises for the linear gap, there are only small changes for the quadratic and HP gaps. In particular, there is no evidence of stabilizing policy for any of the four measures. ${ }^{20}$

Following Clarida, Gali, and Gertler (2000), it has become common practice to specify Taylor rules where the forecast of future inflation, rather than the inflation rate itself, enters the interest rate reaction function. While Clarida, Gali, and Gertler use revised data with actual values of future inflation, Orphanides uses real-time Greenbook forecasts. These are available with one-to-four quarter horizons, but only the one-quarter forecast is available starting in 1966:1. For the purpose of comparison with the findings using real-time inflation rates, we first report results with one-quarter forecasts starting in both 1966:1 and 1969:1. In contrast with our actual real-time inflation rates, which are annualized four quarter averages, the one-quarter forecast is simply the annualized quarterly rate.

Estimated Taylor rules with one-quarter inflation forecasts are reported in Table 1 using CEA output gaps for 1969:1 - 1979:2 and CEA-forecast output gaps for 1966:1 - 1979:2. With the CEA gaps, the inflation coefficient rises from 0.57 (actual inflation) to 1.17 (inflation forecast), although neither of the estimates is significantly different from unity. The output gap coefficient falls from 0.56 (actual) to 0.50 (forecast), exactly matching Taylor's original

\footnotetext{
${ }^{20}$ Nelson (2005), using output gap data from Orphanides (2004), reports an inflation coefficient of 0.82 , so that policy was not stabilizing, for the 1970:1 - 1978:1 period when Arthur Burns was Chairman of the Federal Reserve.
} 
postulated values, and the interest rate smoothing coefficient falls. With the CEA-forecast gaps for $1966: 1-1979: 2$, the estimates are even more successful. The inflation coefficient is 1.63 and significantly different from unity, the output gap coefficient is 0.57 , the interest rate smoothing coefficient is 0.72 , and the implied inflation target is 0.84 , even smaller than Taylor's postulated value of 2.0 These results are very similar to those in Orphanides (2004) that caused him to conclude that the Taylor rule held during the period. ${ }^{21}$

Table 1 also reports estimates with one-quarter inflation forecasts for the other real-time output gaps. For the linear output gap, the inflation coefficient rises from 0.95 (actual inflation) to 1.32 (inflation forecast) for 1969:1 - 1979:2 and from 0.71 (actual) to 1.62 (forecast) for 1966:1 - 1979:2, with both inflation forecast coefficients significantly different from unity. The implied inflation targets with one-quarter inflation forecasts are 2.09 for 1969:1 - 1979:2 and 4.52 for 1966:1 - 1979:2. For the quadratic output gap, the inflation coefficient rises from 0.85 (actual inflation) to 1.03 (inflation forecast) for 1969:1 - 1979:2 and from 0.82 (actual) to 1.50 (forecast) for 1966:1 - 1979:2, although neither of the inflation forecast coefficients are significantly different from unity. For the HP output gap, the inflation coefficient rises from 0.11 (actual inflation) to 0.95 (inflation forecast) for 1969:1 - 1979:2 and from 0.06 (actual) to 0.97 (forecast) for 1966:1 - 1979:2, although neither of the inflation forecast coefficients are significantly different from unity.

Estimation results for two, three, and four quarter inflation forecasts are reported in Table 2, for which the inflation data is consecutively available starting in 1968:4, 1973:3, and 1974:2, respectively. Figure 4 depicts the actual inflation rates and the one-to-four quarter inflation

\footnotetext{
${ }^{21}$ There are minor differences because Orphanides (2004) included two lags of the interest rate. Orphanides (2000) produced very similar results with one lag.
} 
forecasts. ${ }^{22}$ The two and three quarter forecasts are annualized two and three quarter averages. With the linear output gaps, the inflation coefficients are 1.61 (two-quarter forecast), 1.63 (threequarter forecast), and 1.55 (four-quarter forecast), with the two and three-quarter inflation forecast coefficients significantly different from unity. The implied inflation targets are 3.70 (two-quarter forecast) and 3.33 (three-quarter forecast). The inflation forecast coefficients for the quadratic, CEA, and CEA-forecast output gaps are stabilizing but not significantly different from one, resulting in the inflation target not being well-defined. ${ }^{23}$ The coefficients for the HP gaps are either not stabilizing (two-quarter) or unreasonably large (three and four-quarter), and are never significantly different from one.

The results with inflation forecasts are different than with inflation rates in several respects. For the linear output gaps, the inflation coefficients are stabilizing and mostly significantly different from unity. For the quadratic, CEA, and CEA-forecast output gaps, the inflation coefficients are also stabilizing, although usually not significantly different from one. For the HP output gaps, while the inflation forecast coefficients are much larger than the inflation rate coefficients, they are never stabilizing. Some intuition for these results can be found in Figure 4, which depicts inflation rates and one-to-four quarter inflation forecasts for 1966:1 - 1979:2. The inflation forecasts are consistently lower than the inflation rates during 1969 - 1972 and 1974 - 1976, periods that span the two recessions of the 1970s. With inflation forecasts lower than inflation rates, the inflation forecast coefficients need to be larger in order to produce the same changes in the federal funds rate.

\footnotetext{
${ }^{22}$ As illustrated in Figure 4 and described in the notes to Table 2, there are varying numbers on non-consecutive observations and, in one case, a missing observation. We follow Orphanides (2004) and use all available data for the estimation.

${ }^{23}$ The only exception is the two-quarter inflation forecast with CEA-forecast output gaps. In that case, the constant is greater than 2.0, making the implied inflation target negative.
} 
Do these results provide evidence that the Federal Reserve followed a Taylor rule during 1966 - 1979? Although this is the conclusion in Orphanides (2004), we do not believe that it is warranted. For the CEA, linear and quadratic output gaps, we find that policy was stabilizing with inflation forecasts but not stabilizing with inflation rates. It appears that the Federal Reserve was overly optimistic that recessions would bring down inflation, causing it to lower inflation forecasts and to raise interest rates by less than what was actually needed according to the Taylor rule. These results call into question the consensus that Federal Reserve policy should be evaluated by using forecasts. If the Federal Reserve forecasts lower inflation, causing it to not raise interest rates sufficiently and to fail in its task of bringing inflation down, the resultant policy should not be considered effective simply because the coefficient on forecasted inflation was stabilizing. It is also necessary to evaluate policy based on actual inflation and, in that respect, Federal Reserve policy during 1966 - 1979 clearly didn't follow the Taylor rule.

Additional insight into Federal Reserve policy during this period can be attained from the output gap coefficients with Taylor rules that include inflation forecasts, which are between 0.50 and 0.51 (CEA), 0.57 and 0.62 (CEA-forecast), 0.66 and 0.69 (linear), 0.88 and 0.99 (quadratic), and 2.08 and 3.81 (HP). While these are generally smaller than the output gap coefficients for the Taylor rules that include inflation rates, which are 0.56 (CEA), 0.68 (CEA-forecast), 0.70 (linear), 0.96 (quadratic), and 3.69 (HP), the ordering from smallest to largest remains the same. For the linear and quadratic output gaps, the measures which are in accord with the real-time output gaps implied by Okun's Law, the output gap coefficients are larger than those postulated by the Taylor rule, contributing to the conclusion that Federal Reserve policy was too stimulative. The result that Federal Reserve policy followed the Taylor rule with regard to output gaps holds only with the CEA gaps, and is clearly a construct of the CEA gaps being too large. 
For the HP output gaps, the coefficients are clearly too large, consistent with the evidence presented above that the gaps are too small.

\subsection{Stop-Start Monetary Policy}

It is often postulated that the Federal Reserve followed a stop-start monetary policy in the 1970s, producing cycles of rising inflation, higher interest rates, and recession, followed by lower interest rates before inflation could be brought down to acceptable levels. ${ }^{24}$ Levin and Taylor (2009) estimate a variant of a Taylor rule that includes one dummy variable starting in 1970:2, when Arthur Burns became the Federal Reserve Chairman, and a second dummy variable starting in 1976:1, when President Carter took office, to allow for changes in the target inflation rate. They estimate that the Federal Reserve's implied inflation target increased by 1.94 percentage points in 1970:2 and 2.10 percentage points in 1976:2. We implement this idea by adding two dummy variables to Equation (1),

$$
i_{t}^{*}=\pi_{t}+\phi\left(\pi_{t}-\left(\pi^{*}+\delta_{1} D 70+\delta_{2} D 76\right)\right)+\not y_{t}+r^{*}
$$

where $\delta_{1}$ and $\delta_{2}$ represent changes in the inflation target and D70 and D76 equal one starting in 1970:2 and 1976:1, zero otherwise. Combining terms as above and allowing for gradual adjustment of the interest rate, Equation (4) becomes,

$$
i_{t}=(1-\rho)\left(\mu-\omega_{1} D 70-\omega_{2} D 76+\lambda \pi_{t}+\gamma_{t}\right)+\rho i_{t-1}+v_{t}
$$

where $\omega_{1}=\phi \delta_{1}$ and $\omega_{2}=\phi \delta_{2}$.

${ }^{24}$ Meltzer (2009b) characterizes Federal Reserve policymaking in the 1970s as abandoning all concern about inflation whenever the unemployment rate rose to about 7 percent. 
Estimates of Equation (6) with four-quarter average real-time inflation rates and onequarter-ahead inflation forecasts, which are available for both the 1966:1 - 1979:2 and the 1969:1- 1979:2 samples, are reported in Table 3. Since an inflation target cannot be identified unless the coefficient $\phi$ in Equation (5) is greater than zero, we only report changes in the inflation target if the estimate of the inflation coefficient $\lambda$ is significantly different from one and at least one of the coefficients on the dummy variables $\omega$ in Equation (6) are significantly different from zero, although we report the estimates for all cases. With four-quarter average real-time inflation rates, the inflation coefficient $\lambda$ is not significantly different from unity for either sample with any of the four real-time output gap measures. With one-quarter-ahead inflation forecasts for 1966:1 - 1979:2, the inflation coefficients are significantly different from one only for the CEA-forecast gap, but neither of the coefficients on the dummy variables is significant. With one-quarter-ahead inflation forecasts for 1969:1 - 1979:2, however, the inflation coefficients are significantly different from one for all four real-time output gap measures. The significant changes in the inflation target are 2.59 (1970:2) for the linear output gap, $3.75(1970: 2)$ and 6.78 (1976:1) for the quadratic output gap, 3.60 (1976:1) for the CEA gap, and 7.31 (1970:2) and 5.54 (1976:1) for the HP gap.

Table 4 reports estimates with two, three, and four-quarter-ahead inflation forecasts. Since the consecutive data for the three and four-quarter inflation forecasts starts in 1973:3 and 1974:2, respectively, we only include the dummy variable for 1976:1 for these forecasts. The inflation forecast coefficients are significantly different from unity for all five output gap measures over all three forecast horizons. For the two-quarter inflation forecasts, the significant changes in the inflation target are 3.94 (1976:1) for the quadratic gap, $2.66(1976: 1)$ for the CEA gap, 2.12 (1976:1) for the CEA-forecast gap, and 4.49 (1970:2) and 3.97 (1976:1) for the HP 
gap. For the three-quarter inflation forecasts, the significant changes in the inflation target in 1976:1 are 1.84 (linear gap), 4.90 (quadratic gap), 3.00 (CEA gap), 2.81 (CEA-forecast gap), and 4.76 (HP gap). For the four-quarter inflation forecasts, the significant changes in the inflation target in 1976:1 are 2.77 (linear), 5.50 (quadratic), 4.24 (CEA), 3.79 (CEA-forecast), and 4.52 (HP). ${ }^{25}$

Our results do not support Levin and Taylor's conclusion that the Federal Reserve stabilized inflation around an increasing target. ${ }^{26}$ When inflation rates are used, we do not find any specification for which the coefficient $\lambda$ on the inflation rate is significantly greater than unity, and so we cannot identify an inflation target, much less changes in the target. When inflation forecasts are used, $\lambda$ is significantly different from unity and the coefficients on the dummy variables starting in 1970:2 and 1976:1 are significantly different from zero for most specifications. The Federal Reserve raised the nominal interest rate more than point-for-point with inflation forecasts, but not with inflation rates, which does not constitute evidence of inflation stabilization when the forecasts were systematically lower that the actual (or realized) rates for the crucial periods during or following recessions.

\section{Conclusions}

Using graphical, narrative, and econometric analysis, this paper demonstrates that the Federal Reserve did not follow a stabilizing Taylor rule in the 1970s. We first show it is not correct to assert that monetary policy can be characterized by a Taylor rule if real-time, rather than revised, data is used. Instead, the answer to whether the Federal Reserve followed a Taylor

\footnotetext{
${ }^{25}$ The output gap coefficients follow the pattern for specifications without changes in the inflation target. The coefficients on the HP gaps are the largest, followed by quadratic, linear, and CEA.

${ }^{26}$ None of our specifications are exactly comparable to the one in Levin and Taylor (2009). They use data from 1966:1 - 1980:3, use revised CPI inflation rates instead of real-time GDP deflator inflation rates, use current-quarter real-time output gaps instead of one-quarter-lagged or within-quarter-forecasted gaps, and subtract the coefficients on the dummy variables from the inflation rates instead of the regression intercept.
} 
rule in the 1970s depends on which real-time output gap measure is chosen. While, with the CEA output gaps used by Orphanides, the actual path of the federal funds rate is well-described by a rule with Taylor's (1993) original coefficients, the actual rate is consistently below the rate implied by the Taylor rule if either linear, quadratic, or HP detrended real-time gaps are used. Next, we use economic research on the full employment level of unemployment and the natural rate of unemployment published between 1970 and 1977, primarily in Brookings Papers on Economic Activity, along with Okun's Law, to construct a real-time output gap measure for the periods of peak unemployment during the recessions of the early and mid-1970s. We find that linear and quadratic detrended real-time output gaps, which were widely available at the time, are much more congruent with the Okun's Law approximation than either CEA or HP detrended real-time output gaps.

Moving from graphical and narrative to econometric analysis, we show that, with fourquarter-average real-time inflation, the inflation coefficient in the Taylor rule is not significantly greater than one for any real-time output gap measure. This conclusion does not change if, as in Levin and Taylor (2009), shifts in the inflation target starting in 1970:2 and 1976:1 are incorporated in the regression. However, if inflation forecasts replace inflation rates, a different picture emerges. With a constant inflation target, the inflation coefficient is significantly greater than one for all linear and two CEA-forecast output gap specifications. With a shifting inflation target, the results are even stronger, as the inflation coefficient is significantly greater than one for most output gap measures with one to four-quarter inflation forecasts.

The result that the Federal Reserve followed a Taylor rule with inflation coefficients significantly greater than unity for forecasted, but not actual, inflation does not constitute evidence that monetary policy was stabilizing during the 1970s. The Federal Reserve's inflation 
forecasts were consistently lower than either the four-quarter-average real-time inflation rate or the subsequently realized inflation rates during the crucial periods during and following the periods of peak unemployment associated with the recessions of the early and mid-1970s. While the evidence with inflation forecasts shows that the Federal Reserve was trying to contain inflation, the evidence with actual inflation shows why their efforts were unsuccessful. By being too optimistic about how quickly inflation would be lowered by high unemployment, the Federal Reserve failed to raise interest rates enough to conduct stabilizing monetary policy. 


\section{References}

1. Abel, Andrew and Ben Bernanke, 2005. Macroeconomics: Fifth Edition, Pearson Addison Wesley.

2. Barsky, Robert and Lutz Kilian, 2002, "Do We Really Know that Oil Caused the Great Stagflation? A Monetary Alternative," NBER Macroeconomics Annual, 137-183.

3. Burns, Arthur, 1979. "The Anguish of Central Banking," The Per Jacobsson Lecture, Belgrade, Yugoslovia, September 30,

4. Cecchetti, Stephen, Peter Hooper, Bruce Kasman, Kermit Schoenholtz, and Mark Watson, 2007. "Understanding the Evolving Inflation Process," U.S. Monetary Policy Forum.

5. Clarida, Richard, Jordi Gali, and Mark Gertler, 2000. "Monetary Policy Rules and Macroeconomic Stability: Evidence and Some Theory," Quarterly Journal of Economics, 115(1), 147-180.

6. Clark, Peter, 1979. "Potential GNP in the United States, 1948-80," Review of Income and Wealth, 25, 141-165.

7. Dornbusch, Rudiger and Stanley Fischer, 1978. Macroeconomics, McGraw-Hill, New York.

8. "Economic Report of the President," various issues.

9. Friedman, Milton, 1968. "The Role of Monetary Policy," American Economic Review, 58, 1-17.

10. Gordon, Robert J., 1971, "Inflation in Recession and Recovery," Brookings Papers on Economic Activity, No. 1, 105-158.

11. Gordon, Robert J., 1972, "Wage-Price Controls and the Shifting Phillips Curve," Brookings Papers on Economic Activity, No. 2, 385-421.

12. Gordon, Robert J. 1977, "Structural Unemployment and the Productivity of Women," in K. Brunner and A Meltzer, eds., Stabilization of the Domestic and International Economy, CarnegieRochester Conference Series on Public Policy, 181-229.

13. Gordon, Robert J. 1978. Macroeconomics, Little, Brown and Company, Boston.

14. Hall, Robert, 1970. "Why is the Unemployment Rate So High at Full Employment?" Brookings Papers on Economic Activity, No.3, 369-402.

15. Hall, Robert, 1974. "The Process of Inflation in the Labor Market," Brookings Papers on Economic Activity, No.2, 343-393.

16. Hall, Robert, 1999. "Comment on Arturo Estrella and Frederic Mishkin, "Rethinking the Role of NAIRU in Monetary Policy: Implications of Model Formulation and Uncertainty," in in John Taylor, ed., Monetary Policy Rules, University of Chicago Press, 431-434.

17. Kilian, Lutz, 2010, "Oil Price Shocks, Monetary Policy, and Stagflation," in Fry, Renee and Callum Jones, eds., Inflation in an Era of Relative Price Shocks, Reserve Bank of Australia Annual Conference Volume, 60-84.

18. Knotek, Edward, 2007. “How Useful is Okun's Law?" Economic Review, Federal Reserve Bank of Kansas City, Fourth Quarter, 73-103.

19. Kozicki, Sharon and P.A. Tinsley, 2006, "Minding the Gap: Central Bank Estimates of the Unemployment Natural Rate," Computational Economics, 27, 295-327.

20. Kozicki, Sharon and P.A. Tinsley, 2009, "Perhaps the 1970s FOMC Did What it Said it Did," Journal of Monetary Economics, 56, 842-855.

21. Levin, Andrew and John Taylor, 2009, "Falling Behind the Curve: A Positive Analysis of StopStart Monetary Policies and the Great Inflation," forthcoming in Michael Bordo and Athanasios Orphanides, eds., The Great Inflation, University of Chicago Press.

22. Meltzer, Alan, 2009a. "Inflation Nation," The New York Times, May 4, p. A19.

23. Meltzer, Alan, 2009b. "Policy Principles: Lessons from the Fed's Past," in Ciorciari, John and John Taylor, eds., 2009. The Road Ahead for the Fed," Hoover Institution Press, Stanford, California, 13-32.

24. Modigliani, Franco and Lucas Papademos, 1975. "Targets for Monetary Policy in the Coming Year," Brookings Papers on Economic Activity, No.1, 141-163. 
25. Murray, Christian, Alex Nikolsko-Rzhevskyy, and David Papell, 2009. "Inflation Persistence and the Taylor Principle," manuscript, University of Houston.

26. Nelson, Edward, 2005, "The Great Inflation of the Seventies: What Really Happened?", Advances in Macroeconomics, Vol. 5(2), 1-48.

27. Okun, Arthur, 1962. "Potential GNP: Its Measurement and Significance," American Statistical Association, Proceedings of the Business and Economic Statistics Section.

28. Orphanides, Athanasios, 2000. "Activist Stabilization Policy and Inflation: The Taylor Rule in the 1970s," unpublished, Federal Reserve Board.

29. Orphanides, Athanasios, 2003a. "Historical Monetary Policy Analysis and the Taylor Rule," Journal of Monetary Economics, 50, 983-1022.

30. Orphanides, Athanasios, 2003b. "The Quest for Prosperity without Inflation," Journal of Monetary Economics, 50, 633-663.

31. Orphanides, Athanasios, 2004. "Monetary policy rules, Macroeconomic Stability, and Inflation: A View from the Trenches," Journal of Money, Credit, and Banking, 36, 151-175.

32. Orphanides, Athanasios and John Williams, 2005, "The Decline of Activist Stabilization Policy: Natural Rate Misperceptions, Learning, and Expectations," Journal of Economic Dynamics and Control, 29, 1929-1950.

33. Perry, George, 1970. "Changing Labor Markets and Inflation," Brookings Papers on Economic Activity, No.3, 411-441.

34. Phelps, Edmund, 1968. "Money Wage Dynamics and Labor Market Equilibrium," Journal of Political Economy, 678-711.

35. Phelps, Edmund, 1972. "The 1972 Report of the President's Council of Economic Advisers: Economics and Government," American Economic Review, 62, 533-539.

36. "Report of the Pre-Presidential Task Force on Inflation," 1969

37. Taylor, John, 1980, "Output and Price Stability: In International Comparison," Journal of Economic Dynamics and Control, 2, 109-132.

38. Taylor, John, 1993. "Discretion versus Policy Rules in Practice," Carnegie-Rochester Conference Series on Public Policy, 39(1), 195-214.

39. Taylor, John, 1999. "A Historical Analysis of Monetary Policy Rules," in John Taylor, ed., Monetary Policy Rules, University of Chicago Press, 319-347.

40. Taylor, John, 2000. "Comments on Athanasios Orphanides' The Quest for Prosperity without Inflation," unpublished, Stanford University.

41. Taylor, John, 2009, "Taylor Rule Change Will Hurt Fed's Inflation Fight," Commentary on Bloomberg.com, August 25.

42. Wachter, Michael, 1976, "The Changing Cyclical Responsiveness of Wage Inflation," Brookings Papers on Economic Activity, No.1, 115-159.

43. Watson, Mark, 2007. "How Accurate are Real-Time Estimates of Output Trends and Gaps," Federal Reserve Bank of Richmond Economic Quarterly, 93(2), 143-161.

44. Woodford, Michael, 2003, Interest and Prices, Princeton University Press. 
Figure 1: CEA and HP Output Gaps

Real-Time and Revised Output Gap

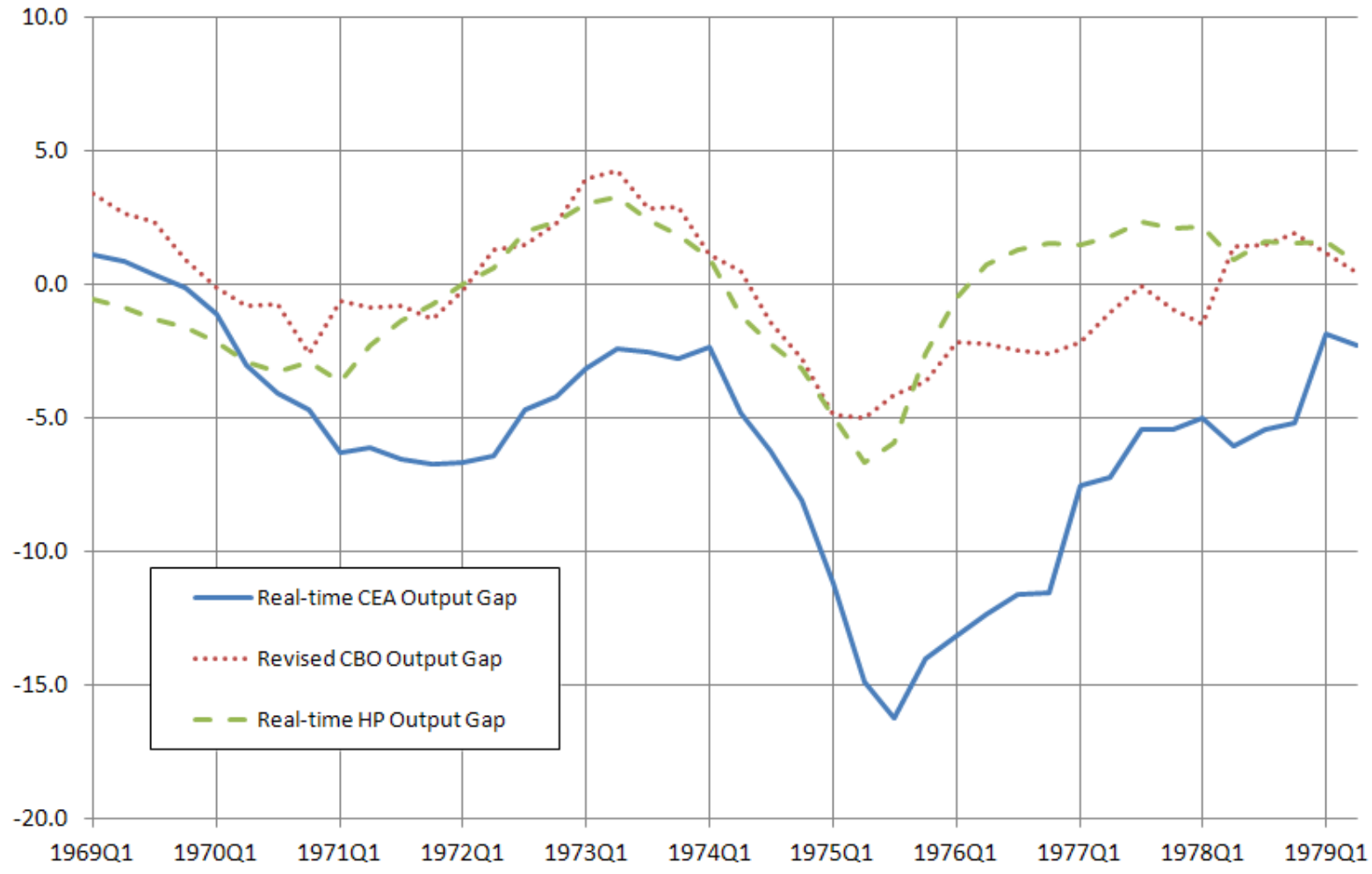

Actual and Implied Federal Funds Rate

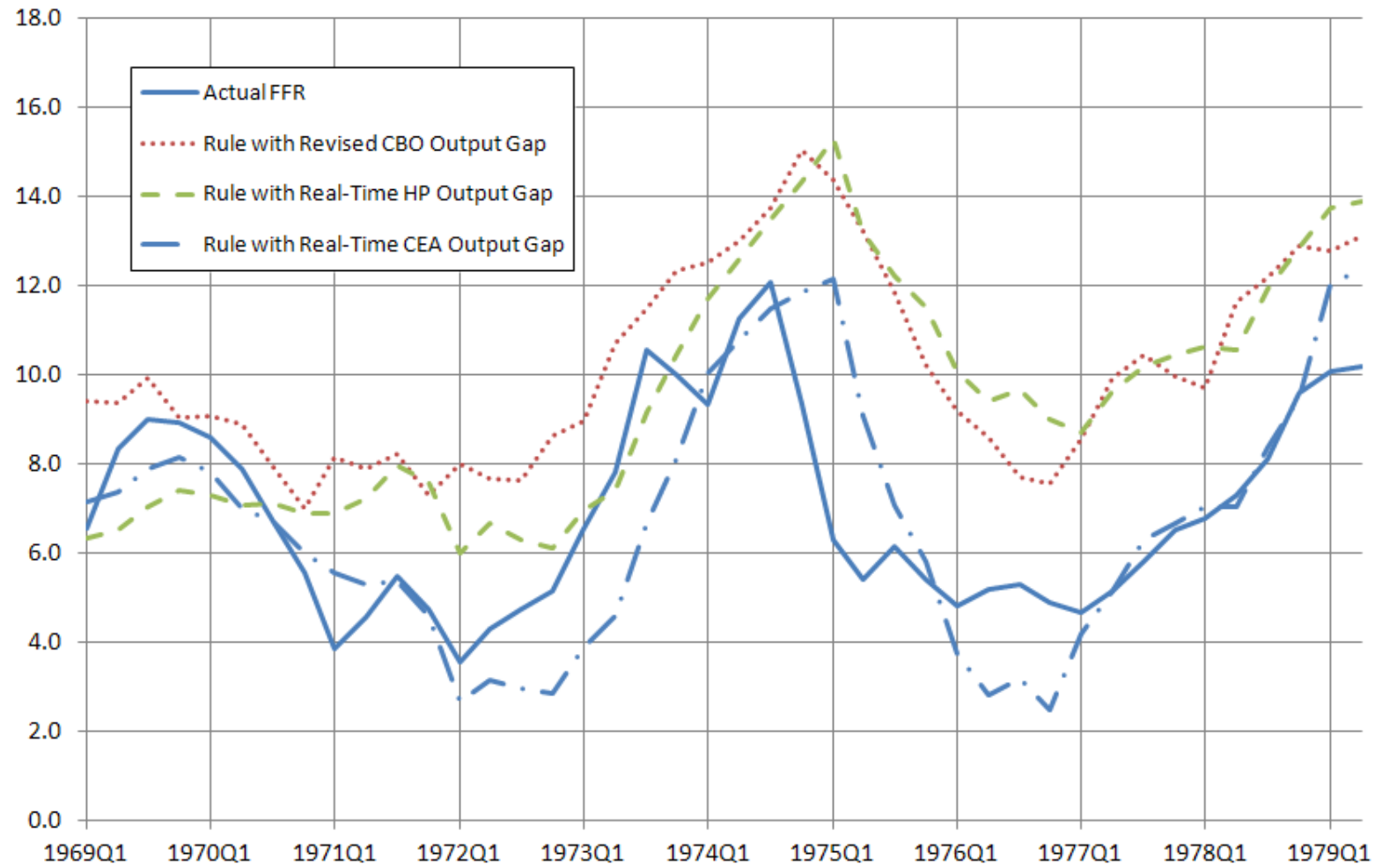


Figure 2: Linear Output Gap

Real-Time and Revised Output Gaps
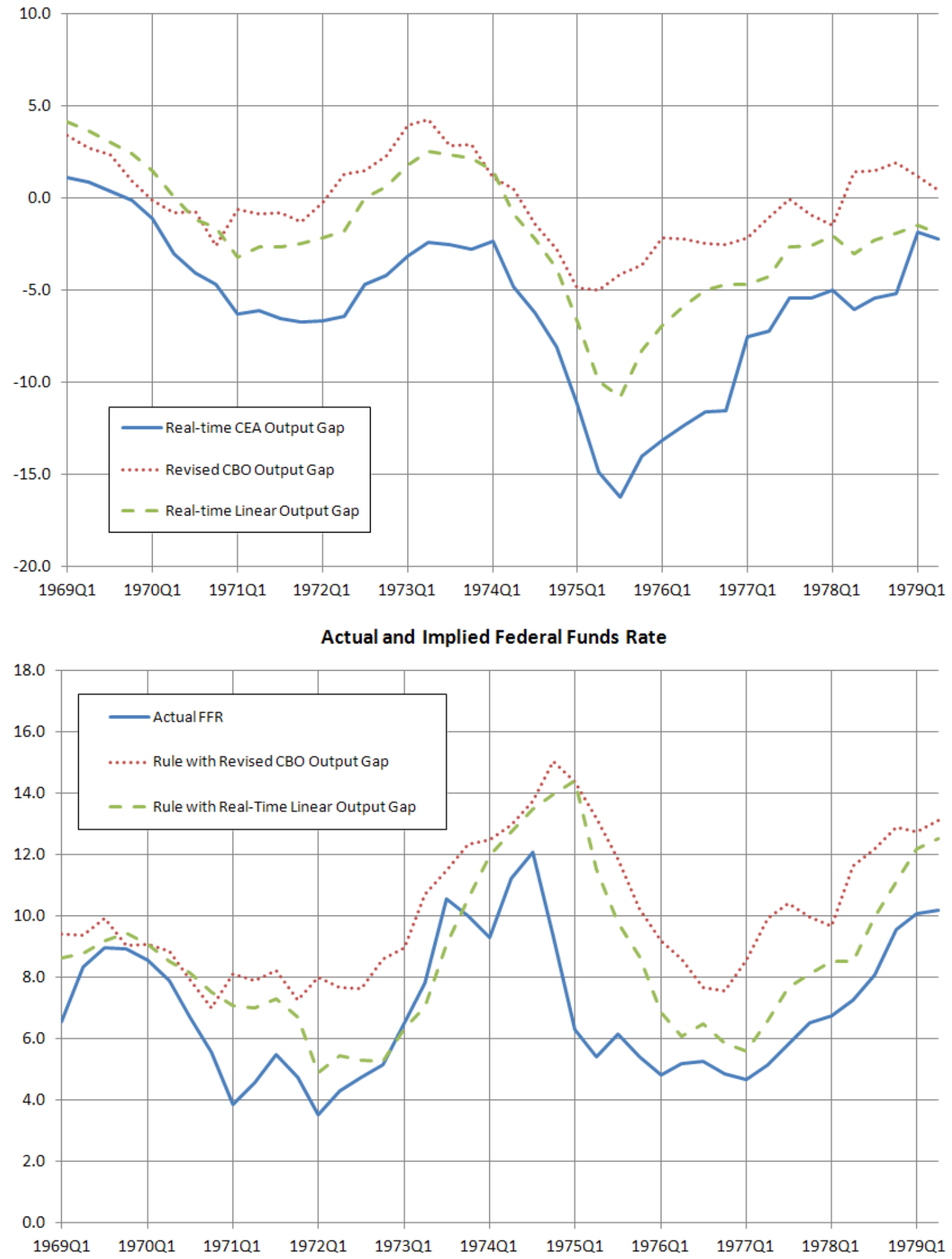
Figure 3: Quadratic Output Gap

Real-Time and Revised Output Gap
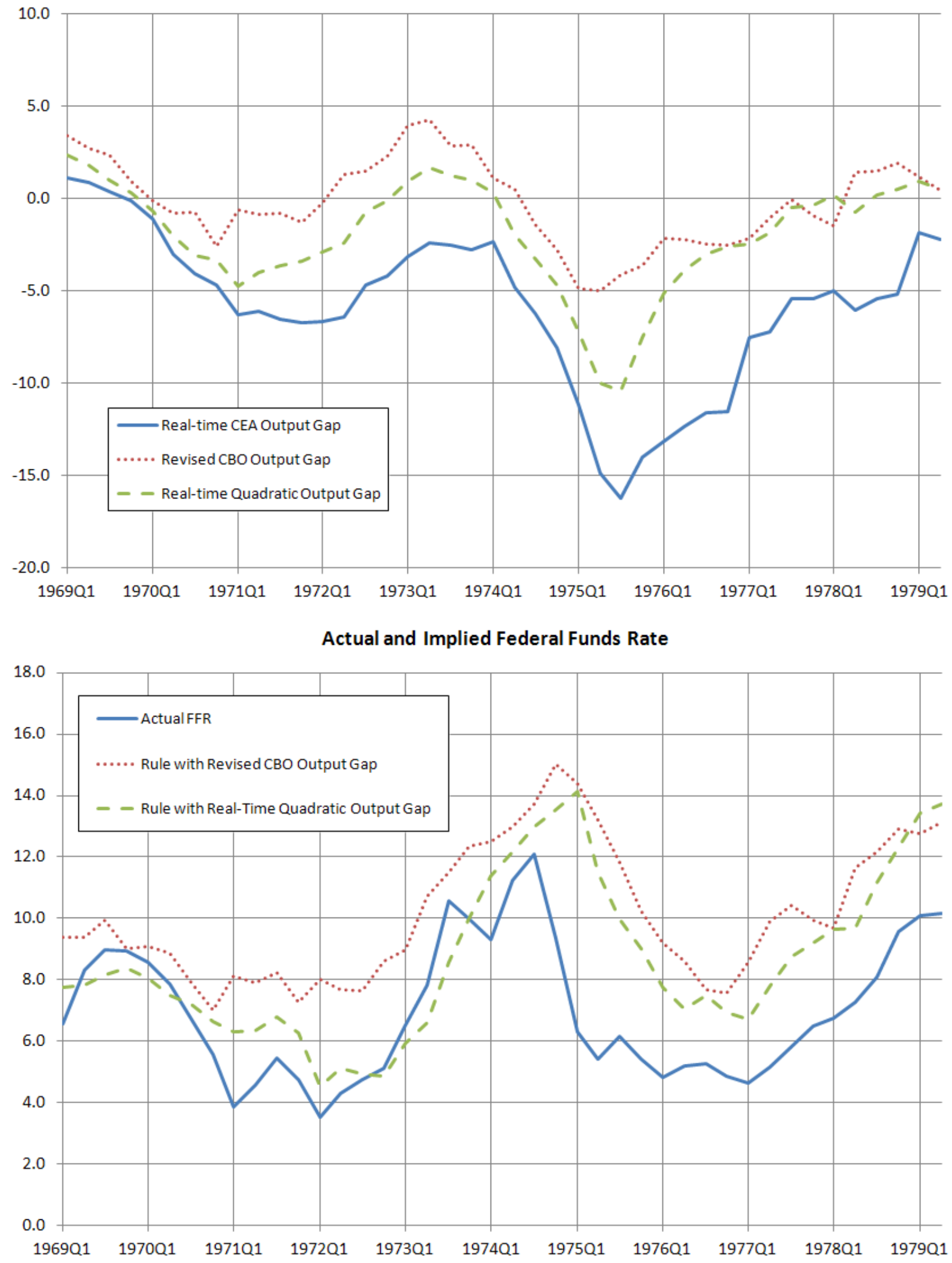
Figure 4

Real-time Inflation and Inflation Forecasts

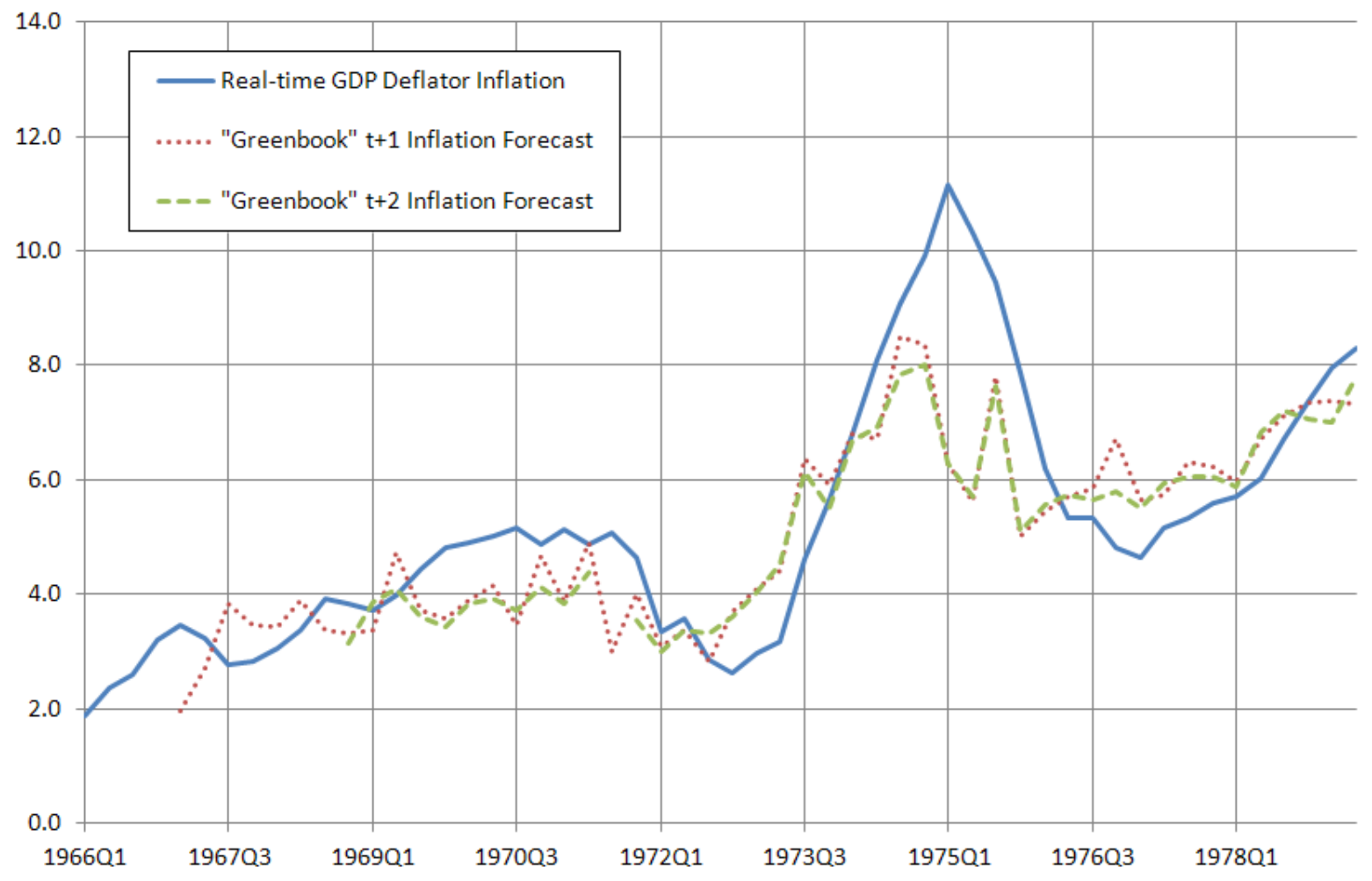

Real-time Inflation and Inflation Forecasts

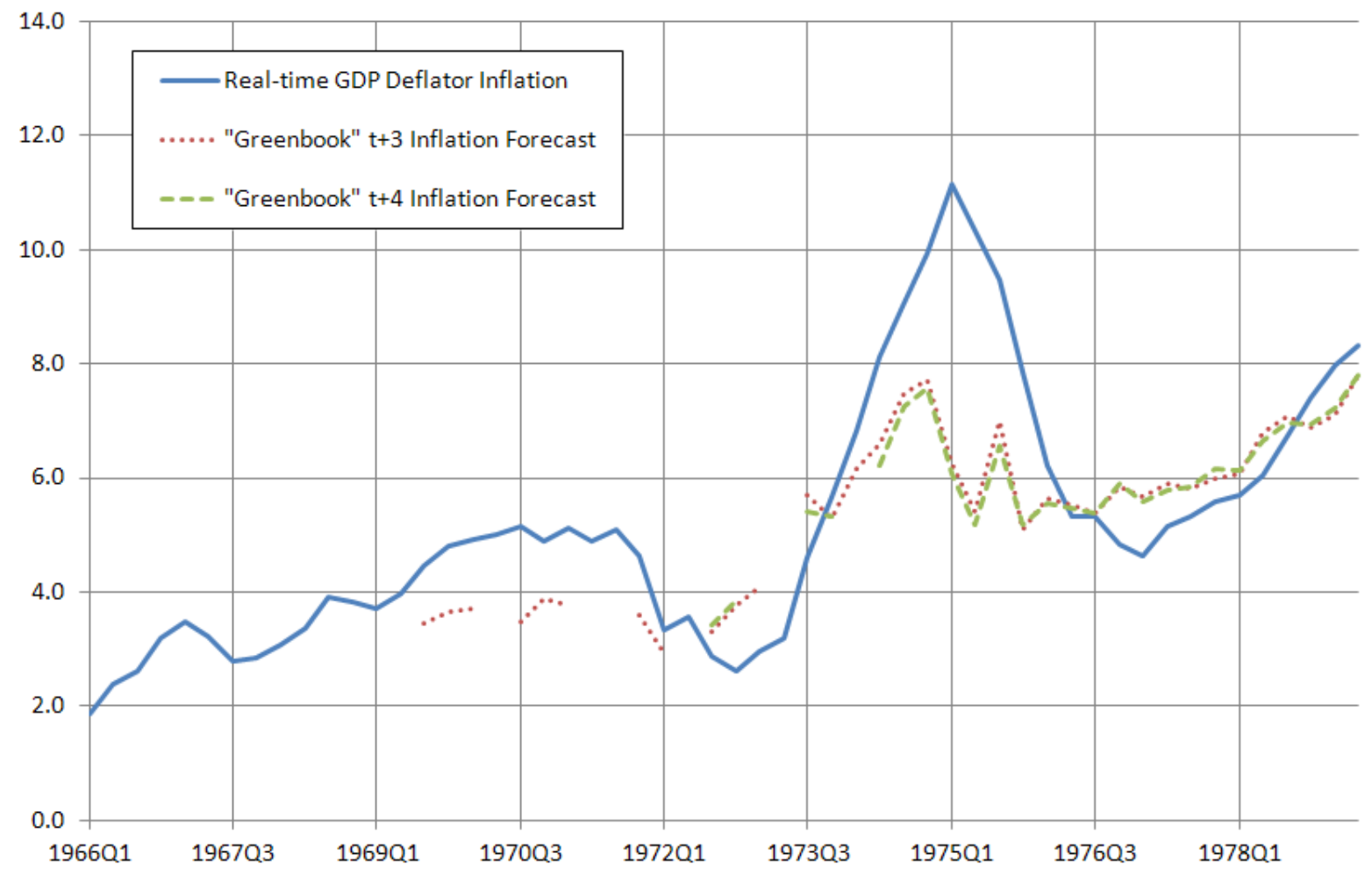


Table 1: Taylor Rule Estimates with Real-Time Inflation and Output Gaps

\begin{tabular}{|c|c|c|c|c|c|c|c|c|}
\hline \multirow[b]{2}{*}{ Output gap measures: } & \multicolumn{4}{|c|}{ 1969:1--1979:2 } & \multicolumn{4}{|c|}{ 1966:1--1979:2 } \\
\hline & Linear & Quadratic & CEA t|t-1 & HP & Linear & Quadratic & CEA tit & HP \\
\hline \multicolumn{9}{|c|}{ Panel A: Four-quarter average inflation rate } \\
\hline Inflation, $\lambda$ & $\begin{array}{c}0.95 \\
(0.24)\end{array}$ & $\begin{array}{c}0.85 \\
(0.20)\end{array}$ & $\begin{array}{c}0.57 \\
(0.34)\end{array}$ & $\begin{array}{l}-0.11 \\
(1.85)\end{array}$ & $\begin{array}{c}0.71 \\
(0.90)\end{array}$ & $\begin{array}{c}0.82 \\
(0.67)\end{array}$ & $\begin{array}{c}0.96 \\
(0.42)\end{array}$ & $\begin{array}{c}0.06 \\
(1.18)\end{array}$ \\
\hline Output gap, $\gamma$ & $\begin{array}{c}0.70 \\
(0.08)\end{array}$ & $\begin{array}{c}0.96 \\
(0.20)\end{array}$ & $\begin{array}{c}0.56 \\
(0.13)\end{array}$ & $\begin{array}{c}3.69 \\
(4.78)\end{array}$ & $\begin{array}{c}0.70 \\
(0.23)\end{array}$ & $\begin{array}{c}0.98 \\
(0.38)\end{array}$ & $\begin{array}{c}0.68 \\
(0.20)\end{array}$ & $\begin{array}{c}3.24 \\
(3.52)\end{array}$ \\
\hline Smoothing, $\rho$ & $\begin{array}{c}0.42 \\
(0.13)\end{array}$ & $\begin{array}{c}0.62 \\
(0.08)\end{array}$ & $\begin{array}{c}0.66 \\
(0.10)\end{array}$ & $\begin{array}{c}0.94 \\
(0.08)\end{array}$ & $\begin{array}{c}0.82 \\
(0.14)\end{array}$ & $\begin{array}{c}0.84 \\
(0.10)\end{array}$ & $\begin{array}{c}0.78 \\
(0.11)\end{array}$ & $\begin{array}{c}0.93 \\
(0.08)\end{array}$ \\
\hline Constant, $\mu$ & $\begin{array}{c}2.94 \\
(1.33)\end{array}$ & $\begin{array}{c}4.11 \\
(1.08)\end{array}$ & $\begin{array}{c}7.16 \\
(2.28)\end{array}$ & $\begin{array}{c}10.34 \\
(13.82)\end{array}$ & $\begin{array}{c}3.89 \\
(4.86)\end{array}$ & $\begin{array}{c}3.67 \\
(3.66)\end{array}$ & $\begin{array}{c}5.18 \\
(2.64)\end{array}$ & $\begin{array}{c}8.82 \\
(8.75)\end{array}$ \\
\hline$R$-squared & 0.83 & 0.85 & 0.80 & 0.81 & 0.79 & 0.81 & 0.81 & 0.82 \\
\hline Panel B: One-quarter- & ad inflat & forecast & & & & & & \\
\hline Inflation, $\lambda$ & $\begin{array}{c}1.32 \\
(0.17)\end{array}$ & $\begin{array}{c}1.03 \\
(0.22)\end{array}$ & $\begin{array}{c}1.17 \\
(0.16)\end{array}$ & $\begin{array}{c}0.95 \\
(0.83)\end{array}$ & $\begin{array}{c}1.62 \\
(0.36)\end{array}$ & $\begin{array}{c}1.50 \\
(0.45)\end{array}$ & $\begin{array}{c}1.63 \\
(0.33)\end{array}$ & $\begin{array}{c}0.97 \\
(0.58)\end{array}$ \\
\hline Output gap, $\gamma$ & $\begin{array}{c}0.66 \\
(0.13)\end{array}$ & $\begin{array}{c}0.88 \\
(0.32)\end{array}$ & $\begin{array}{c}0.50 \\
(0.09)\end{array}$ & $\begin{array}{c}2.21 \\
(2.19)\end{array}$ & $\begin{array}{c}0.60 \\
(0.15)\end{array}$ & $\begin{array}{c}0.72 \\
(0.27)\end{array}$ & $\begin{array}{c}0.57 \\
(0.14)\end{array}$ & $\begin{array}{c}1.79 \\
(1.32)\end{array}$ \\
\hline Smoothing, $\rho$ & $\begin{array}{c}0.56 \\
(0.09)\end{array}$ & $\begin{array}{c}0.72 \\
(0.09)\end{array}$ & $\begin{array}{c}0.57 \\
(0.10)\end{array}$ & $\begin{array}{c}0.90 \\
(0.10)\end{array}$ & $\begin{array}{c}0.69 \\
(0.10)\end{array}$ & $\begin{array}{c}0.78 \\
(0.09)\end{array}$ & $\begin{array}{c}0.72 \\
(0.08)\end{array}$ & $\begin{array}{c}0.88 \\
(0.09)\end{array}$ \\
\hline Constant, $\mu$ & $\begin{array}{c}1.33 \\
(0.77)\end{array}$ & $\begin{array}{c}3.46 \\
(1.22)\end{array}$ & $\begin{array}{c}3.75 \\
(0.80)\end{array}$ & $\begin{array}{c}3.51 \\
(5.12)\end{array}$ & $\begin{array}{c}-0.80 \\
(1.62)\end{array}$ & $\begin{array}{c}0.12 \\
(2.07)\end{array}$ & $\begin{array}{c}1.47 \\
(1.31)\end{array}$ & $\begin{array}{c}3.18 \\
(3.15)\end{array}$ \\
\hline$R$-squared & 0.88 & 0.86 & 0.86 & 0.81 & 0.85 & 0.84 & 0.86 & 0.83 \\
\hline
\end{tabular}

Notes: The table presents NLLS estimates of $i_{t}=(1-\rho)\left(\mu+\lambda \pi_{t+h}+\not y_{t}\right)+\rho i_{t-1}$ for $\mathrm{h}=\{-1,1\} . \pi_{t}$ is inflation, $y_{t}$ is the output gap, and $i_{t}$ is the interest rate. Newey-West robust standard errors are in parentheses. CEA tlt- 1 denotes real-time CEA output gaps and CEA tlt denotes real-time CEA-forecast output gaps. 
Table 2: Taylor Rule Estimates with Real-Time Inflation Forecasts and Output Gaps

\begin{tabular}{|c|c|c|c|c|c|}
\hline Output gap measures: & Linear & Quadratic & CEA t|t-1 & CEA t|t & HP \\
\hline \multicolumn{6}{|c|}{ Panel A: Two-quarter-ahead inflation forecasts for 1968:4-1979:2 } \\
\hline \multirow[t]{2}{*}{ Inflation, $\lambda$} & 1.61 & 1.35 & 1.30 & 1.61 & 0.97 \\
\hline & $(0.23)$ & $(0.30)$ & $(0.21)$ & $(0.29)$ & $(0.89)$ \\
\hline \multirow[t]{2}{*}{ Output gap, $\gamma$} & 0.68 & 0.91 & 0.51 & 0.60 & 2.08 \\
\hline & $(0.14)$ & $(0.33)$ & $(0.10)$ & $(0.14)$ & $(1.84)$ \\
\hline \multirow[t]{2}{*}{ Smoothing, $\rho$} & 0.59 & 0.74 & 0.57 & 0.67 & 0.90 \\
\hline & $(0.10)$ & $(0.09)$ & $(0.10)$ & $(0.08)$ & $(0.09)$ \\
\hline \multirow[t]{2}{*}{ Constant, $\mu$} & -0.26 & 1.68 & 3.17 & 2.12 & 3.51 \\
\hline & $(1.04)$ & $(1.38)$ & $(1.04)$ & $(1.22)$ & $(5.39)$ \\
\hline$R$-squared & 0.89 & 0.86 & 0.87 & 0.88 & 0.82 \\
\hline \multicolumn{6}{|c|}{ Panel B: Three-quarter-ahead inflation forecasts for 1973:3-1979:2 } \\
\hline \multirow[t]{2}{*}{ Inflation, $\lambda$} & 1.63 & 1.43 & 1.42 & 1.65 & 2.32 \\
\hline & $(0.27)$ & $(0.45)$ & $(0.31)$ & $(0.41)$ & $(3.31)$ \\
\hline \multirow[t]{2}{*}{ Output gap, $\gamma$} & 0.69 & 0.99 & 0.51 & 0.62 & 3.81 \\
\hline & $(0.17)$ & $(0.45)$ & $(0.12)$ & $(0.17)$ & $(7.32)$ \\
\hline \multirow[t]{2}{*}{ Smoothing, $\rho$} & 0.58 & 0.77 & 0.61 & 0.69 & 0.94 \\
\hline & $(0.10)$ & $(0.09)$ & $(0.11)$ & $(0.09)$ & $(0.11)$ \\
\hline \multirow[t]{2}{*}{ Constant, $\mu$} & -0.10 & 1.41 & 2.60 & 2.13 & -4.52 \\
\hline & $(1.28)$ & $(2.16)$ & $(1.46)$ & $(1.77)$ & (16.67) \\
\hline$R$-squared & 0.88 & 0.86 & 0.85 & 0.87 & 0.82 \\
\hline \multicolumn{6}{|c|}{ Panel C: Four-quarter-ahead inflation forecasts for 1974:2-1979:2 } \\
\hline \multirow[t]{2}{*}{ Inflation, $\lambda$} & 1.55 & 1.27 & 1.27 & 1.44 & 2.15 \\
\hline & $(0.34)$ & $(0.51)$ & $(0.35)$ & $(0.44)$ & $(2.69)$ \\
\hline \multirow[t]{2}{*}{ Output gap, $\gamma$} & 0.69 & 0.94 & 0.51 & 0.61 & 2.80 \\
\hline & $(0.23)$ & $(0.57)$ & $(0.18)$ & $(0.23)$ & $(4.92)$ \\
\hline \multirow[t]{2}{*}{ Smoothing, $\rho$} & 0.62 & 0.79 & 0.66 & 0.72 & 0.92 \\
\hline & $(0.11)$ & $(0.11)$ & $(0.13)$ & $(0.11)$ & $(0.12)$ \\
\hline \multirow{2}{*}{ Constant, $\mu$} & 0.54 & 2.43 & 3.68 & 3.53 & -3.93 \\
\hline & $(1.50)$ & $(2.44)$ & $(1.80)$ & (1.99) & (13.03) \\
\hline$R$-squared & 0.86 & 0.84 & 0.84 & 0.85 & 0.82 \\
\hline
\end{tabular}

Notes: The table presents NLLS estimates of $i_{t}=(1-\rho)\left(\mu+\lambda \pi_{t+h}+\not y_{t}\right)+\rho i_{t-1}$ for $\mathrm{h}=\{2,3,4\} . \pi_{t}$ is inflation, $y_{t}$ is the output gap, and $i_{t}$ is the interest rate. Newey-West robust standard errors are in parentheses. CEA tlt- 1 denotes real-time CEA output gaps and CEA tit denotes real-time CEA-forecast output gaps. 2, 12 and 7 additional observations are available for the 2-, 3- and 4-quarter ahead forecast horizons before the respective samples start. For the 2-quarter ahead forecast horizon, the 1971:3 observation is missing. 
Table 3: Taylor Rule Estimates with Real-Time Inflation, Output Gaps, and Two Structural Breaks

\begin{tabular}{|c|c|c|c|c|c|c|c|c|}
\hline \multirow[b]{2}{*}{ Output gap measures: } & \multicolumn{4}{|c|}{ 1969:1--1979:2 } & \multicolumn{4}{|c|}{ 1966:1--1979:2 } \\
\hline & Linear & Quadratic & CEA t|t-1 & HP & Linear & Quadratic & CEA tit & HP \\
\hline \multicolumn{9}{|c|}{ Panel A: Four-quarter average inflation rate } \\
\hline Inflation, $\lambda$ & $\begin{array}{c}1.01 \\
(0.16)\end{array}$ & $\begin{array}{c}0.97 \\
(0.17)\end{array}$ & $\begin{array}{c}0.54 \\
(0.32)\end{array}$ & $\begin{array}{c}1.29 \\
(0.47)\end{array}$ & $\begin{array}{c}1.00 \\
(0.27)\end{array}$ & $\begin{array}{c}0.76 \\
(0.56)\end{array}$ & $\begin{array}{c}0.90 \\
(0.31)\end{array}$ & $\begin{array}{c}1.40 \\
(0.63)\end{array}$ \\
\hline Output gap, $\gamma$ & $\begin{array}{c}0.79 \\
(0.12)\end{array}$ & $\begin{array}{c}0.89 \\
(0.13)\end{array}$ & $\begin{array}{c}0.62 \\
(0.20)\end{array}$ & $\begin{array}{c}1.82 \\
(0.52)\end{array}$ & $\begin{array}{c}0.93 \\
(0.23)\end{array}$ & $\begin{array}{c}1.19 \\
(0.50)\end{array}$ & $\begin{array}{c}0.84 \\
(0.26)\end{array}$ & $\begin{array}{c}2.23 \\
(0.89)\end{array}$ \\
\hline Smoothing, $\rho$ & $\begin{array}{c}0.38 \\
(0.11)\end{array}$ & $\begin{array}{c}0.46 \\
(0.10)\end{array}$ & $\begin{array}{c}0.68 \\
(0.09)\end{array}$ & $\begin{array}{c}0.75 \\
(0.08)\end{array}$ & $\begin{array}{c}0.63 \\
(0.15)\end{array}$ & $\begin{array}{c}0.81 \\
(0.13)\end{array}$ & $\begin{array}{c}0.74 \\
(0.10)\end{array}$ & $\begin{array}{c}0.83 \\
(0.08)\end{array}$ \\
\hline D1970:2, $\omega_{1}$ & $\begin{array}{l}-0.57 \\
(0.73)\end{array}$ & $\begin{array}{l}-0.02 \\
(0.67)\end{array}$ & $\begin{array}{c}-0.38 \\
(1.72)\end{array}$ & $\begin{array}{c}5.72 \\
(1.44)\end{array}$ & $\begin{array}{c}-2.95 \\
(1.42)\end{array}$ & $\begin{array}{c}-4.13 \\
(3.08)\end{array}$ & $\begin{array}{l}-3.10 \\
(2.23)\end{array}$ & $\begin{array}{c}3.48 \\
(2.32)\end{array}$ \\
\hline $\mathrm{D} 1976: 1, \omega_{2}$ & $\begin{array}{l}-1.19 \\
(0.43)\end{array}$ & $\begin{array}{c}1.34 \\
(0.49)\end{array}$ & $\begin{array}{l}-1.34 \\
(0.96)\end{array}$ & $\begin{array}{c}3.45 \\
(1.39)\end{array}$ & $\begin{array}{l}-1.91 \\
(0.98)\end{array}$ & $\begin{array}{c}0.26 \\
(1.77)\end{array}$ & $\begin{array}{l}-1.13 \\
(1.24)\end{array}$ & $\begin{array}{c}3.69 \\
(1.95)\end{array}$ \\
\hline Constant, $\mu$ & $\begin{array}{c}1.86 \\
(1.03)\end{array}$ & $\begin{array}{c}3.65 \\
(0.93)\end{array}$ & $\begin{array}{c}6.93 \\
(1.70)\end{array}$ & $\begin{array}{c}6.60 \\
(1.94)\end{array}$ & $\begin{array}{l}-0.31 \\
(1.55)\end{array}$ & $\begin{array}{c}1.25 \\
(2.92)\end{array}$ & $\begin{array}{c}3.78 \\
(1.55)\end{array}$ & $\begin{array}{c}3.94 \\
(2.54)\end{array}$ \\
\hline$R$-squared & 0.85 & 0.86 & 0.81 & 0.84 & 0.83 & 0.82 & 0.84 & 0.84 \\
\hline Panel B: One-quarter- & ead infl & tion forecas & & & & & & \\
\hline Inflation, $\lambda$ & $\begin{array}{c}1.39 \\
(0.18)\end{array}$ & $\begin{array}{c}1.36 \\
(0.17)\end{array}$ & $\begin{array}{c}1.30 \\
(0.17)\end{array}$ & $\begin{array}{c}1.71 \\
(0.41)\end{array}$ & $\begin{array}{c}1.49 \\
(0.33)\end{array}$ & $\begin{array}{c}1.51 \\
(0.43)\end{array}$ & $\begin{array}{c}1.57 \\
(0.30)\end{array}$ & $\begin{array}{c}1.96 \\
(0.68)\end{array}$ \\
\hline Output gap, $\gamma$ & $\begin{array}{c}0.56 \\
(0.12)\end{array}$ & $\begin{array}{c}0.63 \\
(0.13)\end{array}$ & $\begin{array}{c}0.41 \\
(0.06)\end{array}$ & $\begin{array}{c}1.05 \\
(0.31)\end{array}$ & $\begin{array}{c}0.71 \\
(0.22)\end{array}$ & $\begin{array}{c}0.76 \\
(0.22)\end{array}$ & $\begin{array}{c}0.60 \\
(0.15)\end{array}$ & $\begin{array}{c}1.41 \\
(0.60)\end{array}$ \\
\hline Smoothing, $\rho$ & $\begin{array}{c}0.50 \\
(0.11)\end{array}$ & $\begin{array}{c}0.53 \\
(0.10)\end{array}$ & $\begin{array}{c}0.46 \\
(0.12)\end{array}$ & $\begin{array}{c}0.69 \\
(0.11)\end{array}$ & $\begin{array}{c}0.68 \\
(0.12)\end{array}$ & $\begin{array}{c}0.74 \\
(0.11)\end{array}$ & $\begin{array}{c}0.68 \\
(0.10)\end{array}$ & $\begin{array}{c}0.79 \\
(0.10)\end{array}$ \\
\hline D1970:2, $\omega_{1}$ & $\begin{array}{c}1.01 \\
(0.55)\end{array}$ & $\begin{array}{c}1.35 \\
(0.51)\end{array}$ & $\begin{array}{c}0.90 \\
(0.69)\end{array}$ & $\begin{array}{c}5.19 \\
(1.06)\end{array}$ & $\begin{array}{l}-1.68 \\
(1.42)\end{array}$ & $\begin{array}{l}-1.77 \\
(1.87)\end{array}$ & $\begin{array}{l}-1.54 \\
(1.34)\end{array}$ & $\begin{array}{c}3.07 \\
(2.03)\end{array}$ \\
\hline D1976:1, $\omega_{2}$ & $\begin{array}{c}0.65 \\
(0.54)\end{array}$ & $\begin{array}{c}2.44 \\
(0.49)\end{array}$ & $\begin{array}{c}1.08 \\
(0.59)\end{array}$ & $\begin{array}{c}3.93 \\
(1.22)\end{array}$ & $\begin{array}{c}0.07 \\
(0.92)\end{array}$ & $\begin{array}{c}2.07 \\
(1.08)\end{array}$ & $\begin{array}{c}1.16 \\
(0.84)\end{array}$ & $\begin{array}{c}4.45 \\
(1.92)\end{array}$ \\
\hline Constant, $\mu$ & $\begin{array}{c}1.80 \\
(0.87)\end{array}$ & $\begin{array}{c}3.01 \\
(0.81)\end{array}$ & $\begin{array}{c}3.62 \\
(0.69)\end{array}$ & $\begin{array}{c}4.25 \\
(1.17)\end{array}$ & $\begin{array}{l}-1.24 \\
(1.56)\end{array}$ & $\begin{array}{c}-0.69 \\
(1.90)\end{array}$ & $\begin{array}{c}1.09 \\
(1.08)\end{array}$ & $\begin{array}{c}1.03 \\
(2.02)\end{array}$ \\
\hline$R$-squared & 0.88 & 0.89 & 0.87 & 0.87 & 0.86 & 0.85 & 0.87 & 0.86 \\
\hline
\end{tabular}

Notes: The table presents NLLS estimates of $i_{t}=(1-\rho)\left(\mu-\omega_{1} D 1970 Q 2-\omega_{2} D 1976 Q 1+\lambda \pi_{t+h}+\not y_{t}\right)+\rho i_{t-1}$ for $\mathrm{h}=\{-1,1\}$. $\pi_{t}$ is inflation, $y_{t}$ is the output gap, and $i_{t}$ is the interest rate. Newey-West robust standard errors are in parentheses. CEA ttt-1 denotes real-time CEA output gaps and CEA tt denotes real-time CEA-forecast output gaps. D1970Q2 and D1976Q1 are dummy variables that equal 1 starting 1970Q2 and 1976Q1, respectively, and 0 otherwise. 
Table 4: Taylor Rule Estimates with Real-Time Inflation Forecasts, Output Gaps, and Structural Breaks

\begin{tabular}{|c|c|c|c|c|c|}
\hline Output gap measures: & Linear & Quadratic & CEA tlt-1 & CEA tlt & HP \\
\hline \multicolumn{6}{|c|}{ Panel A: Two-quarter-ahead inflation forecasts for 1968:4-1979:2 } \\
\hline \multirow[t]{2}{*}{ Inflation, $\lambda$} & 1.68 & 1.66 & 1.47 & 1.75 & 2.12 \\
\hline & $(0.25)$ & $(0.27)$ & $(0.20)$ & $(0.27)$ & $(0.52)$ \\
\hline \multirow[t]{2}{*}{ Output gap, $\gamma$} & 0.61 & 0.70 & 0.41 & 0.50 & 1.17 \\
\hline & $(0.13)$ & $(0.15)$ & $(0.05)$ & $(0.08)$ & $(0.34)$ \\
\hline \multirow[t]{2}{*}{ Smoothing, $\rho$} & 0.54 & 0.60 & 0.44 & 0.58 & 0.71 \\
\hline & $(0.12)$ & $(0.12)$ & $(0.12)$ & $(0.10)$ & $(0.10)$ \\
\hline \multirow[t]{2}{*}{$\mathrm{D} 1970: 2, \omega_{1}$} & 0.30 & 0.53 & 1.16 & 0.38 & 5.03 \\
\hline & $(0.97)$ & (1.12) & $(0.75)$ & $(1.12)$ & $(1.44)$ \\
\hline \multirow[t]{2}{*}{ D1976:1, $\omega_{2}$} & 0.73 & 2.60 & 1.25 & 1.59 & 4.45 \\
\hline & $(0.55)$ & $(0.61)$ & $(0.56)$ & $(0.70)$ & $(1.31)$ \\
\hline \multirow[t]{2}{*}{ Constant, $\mu$} & -0.25 & 0.85 & 3.08 & 1.56 & 2.08 \\
\hline & $(1.29)$ & $(1.40)$ & $(0.82)$ & $(1.23)$ & (1.69) \\
\hline$R$-squared & 0.89 & 0.89 & 0.88 & 0.89 & 0.88 \\
\hline \multicolumn{6}{|c|}{ Panel B: Three-quarter-ahead inflation forecasts for 1973:3-1979:2 } \\
\hline \multirow[t]{2}{*}{ Inflation, $\lambda$} & 1.68 & 1.63 & 1.52 & 1.73 & 2.25 \\
\hline & $(0.25)$ & $(0.28)$ & $(0.25)$ & $(0.29)$ & $(1.34)$ \\
\hline \multirow[t]{2}{*}{ Output gap, $\gamma$} & 0.60 & 0.70 & 0.43 & 0.49 & 1.87 \\
\hline & $(0.14)$ & $(0.20)$ & $(0.08)$ & $(0.10)$ & (1.67) \\
\hline \multirow[t]{2}{*}{ Smoothing, $\rho$} & 0.47 & 0.54 & 0.46 & 0.53 & 0.84 \\
\hline & $(0.16)$ & $(0.16)$ & $(0.17)$ & $(0.14)$ & $(0.15)$ \\
\hline \multirow[t]{2}{*}{ D1976:1, $\omega_{2}$} & 1.25 & 3.09 & 1.56 & 2.05 & 5.95 \\
\hline & $(0.53)$ & $(0.54)$ & $(0.67)$ & $(0.75)$ & $(3.66)$ \\
\hline \multirow[t]{2}{*}{ Constant, $\mu$} & -0.12 & 0.98 & 2.16 & 1.64 & -2.23 \\
\hline & $(1.20)$ & $(1.33)$ & (1.18) & $(1.31)$ & $(5.83)$ \\
\hline$R$-squared & 0.89 & 0.89 & 0.87 & 0.88 & 0.84 \\
\hline \multicolumn{6}{|c|}{ Panel C: Four-quarter-ahead inflation forecasts for 1974:2-1979:2 } \\
\hline \multirow[t]{2}{*}{ Inflation, $\lambda$} & 1.70 & 1.64 & 1.49 & 1.67 & 2.26 \\
\hline & $(0.28)$ & $(0.31)$ & $(0.29)$ & $(0.31)$ & $(0.92)$ \\
\hline \multirow[t]{2}{*}{ Output gap, $\gamma$} & 0.53 & 0.61 & 0.39 & 0.43 & 1.31 \\
\hline & $(0.11)$ & $(0.13)$ & $(0.06)$ & $(0.06)$ & $(0.75)$ \\
\hline \multirow[t]{2}{*}{ Smoothing, $\rho$} & 0.35 & 0.43 & 0.39 & 0.47 & 0.74 \\
\hline & $(0.21)$ & $(0.21)$ & $(0.21)$ & $(0.17)$ & $(0.19)$ \\
\hline \multirow[t]{2}{*}{$\mathrm{D} 1976: 1, \omega_{2}$} & 1.94 & 3.52 & 2.08 & 2.54 & 5.70 \\
\hline & $(0.54)$ & $(0.71)$ & $(0.79)$ & $(0.87)$ & $(2.41)$ \\
\hline \multirow[t]{2}{*}{ Constant, $\mu$} & 0.10 & 1.07 & 2.51 & 2.09 & -2.59 \\
\hline & (1.42) & (1.57) & (1.35) & (1.48) & (4.07) \\
\hline$R$-squared & 0.89 & 0.88 & 0.86 & 0.88 & 0.84 \\
\hline
\end{tabular}

Notes: The table presents NLLS estimates of $i_{t}=(1-\rho)\left(\mu-\omega_{1} D 1970 Q 2-\omega_{2} D 1976 Q 1+\lambda \pi_{t+h}+\not y_{t}\right)+\rho i_{t-1}$ for $\mathrm{h}=\{2,3,4\} . \pi_{t}$ is inflation, $y_{t}$ is the output gap, and $i_{t}$ is the interest rate. Newey-West robust standard errors are in parentheses. CEA tlt-1 denotes real-time CEA output gaps and CEA tit denotes real-time CEA-forecast output gaps. D1970Q2 and D1976Q1 are dummy variables that equal 1 starting 1970Q2 and 1976Q1, respectively, and 0 otherwise. 